\title{
Anatomical Theatres and the Teaching of Anatomy in Early Modern Spain
}

\author{
ÀLVAR MARTÍNEZ-VIDAL and JOSÉ PARDO-TOMÁS*
}

\section{Introduction}

The knowledge and interpretation of the practice of anatomy in the Renaissance have recently undergone a profound change. To a large extent, this is the result of new directions taken in the social and cultural history of medicine since the late $1970 \mathrm{~s} .{ }^{1}$ In the last decade, several important works have been published, which are undeniable evidence of this historiographical change. ${ }^{2}$ However, there has as yet been no attempt to produce a synthetic view of all this new work, in which there is not always agreement. Such a synthesis would undoubtedly produce an interpretation of Renaissance anatomy very different from the traditional one.

We believe that in order to reach a more complete understanding of this subject, the historian must look at countries and cities that have until now been seen as of little importance, and aspects that have been considered only tangentially. This article studies both these features. On the one hand, it draws on new sources in order to place the practice of anatomy in the Hispanic kingdoms within the wider European perspective; ${ }^{3}$ on the other,

(C) Àlvar Martínez-Vidal and José Pardo-Tomás 2005

* Àlvar Martínez-Vidal, MD, PhD (Centre d'Estudis d'Història de les Ciències, Universitat Autònoma of Barcelona), José Pardo-Tomás, PhD (Department d'Història de la Ciència, Institució "Milà i Fontanals", CSIC, Barcelona). Address for correspondence: Àlvar Martínez-Vidal; José Pardo-Tomás, CSIC, Carrer Egipcíaques, 15, E-08001 Barcelona (Spain); e-mail: pppardo@bicat.csic.es.

We are grateful to Miguel Tomás-Valiente, Paz Jordà-Rodríguez and Caroline Tonson-Rye for the English translation, and to Enrique Perdiguero and Maurizio Rippa Bonati for their comments and suggestions. Of course, any errors that remain are our own.

\footnotetext{
${ }^{1}$ As regards anatomy especially, the pioneering role of some articles published in the 1970s is beyond doubt. The most outstanding are those of T Gelfand, "The "Paris manner" of dissection: student anatomical dissection in early eighteenth-century Paris', Bull. Hist. Med., 1972, 46: 99-130; H-K Schmutz, 'Barocke und klassizistische Elemente in der anatomischen Abbildung', Gesnerus, 1978, 35: 54-65; and A Cunningham, 'The kinds of anatomy', Med. Hist, 1975, 19: 1-19.

${ }^{2}$ A Carlino, La fabbrica del corpo: libri e dissezione nel Rinascimento, Torino, Einaudi, 1994;
}

English ed., Books of the body: anatomical ritual and Renaissance learning, University of Chicago Press, 1999; N Siraisi, 'Vesalius and human diversity in De humani corporis fabrica', J. Warburg and Courtland Inst., 1994, 57: 60-88; and idem, 'Vesalius and the reading of Galen's teleology', Renaiss. Q., 1997, 50: 1-37; J J Barcia Goyanes, El mito de Vesalio, Valencia, Real Academia de MedicinaUniversitat de València, 1994; J Sawday, The body emblazoned: dissection and the human body in Renaissance culture, London and New York, Routledge, 1995; A Cunningham, The anatomical Renaissance: the resurrection of the anatomical projects of the Ancients, Aldershot, Scolar Press, 1997; $\mathrm{R}$ French, Dissection and vivisection in the European Renaissance, Aldershot, Ashgate, 1999.

${ }^{3}$ Spain has attracted the attention of some authors, if only to comment on Vesalius's presence, as surgeon, at the court of Charles V. More important contributions have been made by C D O'Malley, 'Pedro Jimeno: Valencian anatomist of the mid-sixteenth century', in A G Debus (ed.), Science, medicine and society in the Renaissance, 2 vols, London, Heinemann, 1972, vol. 1, pp. 69-72; idem, 'Los saberes morfológicos en el Renacimiento: la anatomía', in P Laín Entralgo (ed.), Historia Universal de la Medicina, 7 vols, Barcelona, Salvat, 1973, vol. 4, pp. 43-77; and J M López Piñero, 'La disección y el saber anatómico en la España de la primera mitad del siglo XVI', Cuad. Hist. Med. Española, 1974, 13: 51-110. 


\section{Àlvar Martínez-Vidal and José Pardo-Tomás}

it answers some basic questions-where, how and why-about the different places where Renaissance anatomical practices took place.

In this respect, the examples of the seven Spanish cities discussed here testify to the fact that from the sixteenth century the practice of dissection became established in their universities, with support from the Crown in some cases and from town councils in others, and that hospital grounds became the preferred space for the construction of anatomy theatres.

The main purpose of this article is to show the rise and evolution of the sites in which anatomical dissections were performed, based on the belief that the place dedicated to the practice of anatomy in early modern Europe is of the utmost importance for a better understanding of the practices, learning, assumptions, purposes and motives with which anatomical knowledge was worked out during that extensive period. If we wish to see whether there was an epistemological change in anatomical knowledge, a unique "Vesalian reform" or, indeed, several "research plans", the products of various intellectual, artistic, philosophical or religious options; or whether we want answers to why at that moment and in specific places dissection became a habitual practice for students, artists, philosophers, physicians and surgeons, it is essential to know the material circumstances and the conditions of the space where the anatomical practices were performed. This area must be understood not only as an architectural, physical site, but also as a stage-set prepared for a variety of audiences, authorized and regulated by those in power, and socially recognized.

For this purpose, we have drawn on iconographic, literary, legal, administrative and notarial sources, so as to reach beyond the anatomists' own writings, the classic source most used by medical historians. In fact, these texts seldom make explicit references to the place in which the authors carried out their dissections, and when they do, it is clearly for some specific reason, to refer to a minor detail of daily practice. However, it should not be supposed that the anatomists' reluctance to spend time describing the site where their anatomical demonstrations took place was due either to its questionable nature or to regulations or prohibitions. In spite of the rare, imprecise and sparse references, such practices and the existence of such sites were probably so usual that the anatomists did not consider it necessary to justify them or to give details of location, disposition or material conditions.

To deny a significant role to alleged prohibitions and regulations by no means signifies that they did not play a very important part in the way anatomical practices were carried out. On the contrary, among the diverse elements involved in the complex network of interests to be found behind the practice of dissection in Europe at this time, intervention by those in authority in a variety of areas - the university, the town council, the Church, the state or the monarchy-is a basic element.

The examples given below show how deeply the political authorities, academic institutions, and group interests were implicated in the vicissitudes of the construction of specific places dedicated to anatomical practice, whether in Salamanca or Barcelona, Bologna or Padova, Leyden or Paris. ${ }^{4}$ The wide variety of sources used shows the procedures by which

\footnotetext{
${ }^{4}$ See, for instance, J Sawday, 'The Leiden anatomy theatre as a source for Davenant's "Cabinet of death"

in "Gondibert" , Notes and Queries, 1983, 30: 437-9; G Ferrari, 'Public anatomy lessons and the carnival: the
} 


\section{Anatomical Theatres in Early Modern Spain}

"a place for anatomy", temporary or permanent, was created either by renovating a preexisting structure or by building from scratch an authentic "theatre". They also indicate the regulations for the professors and those in charge of the anatomies, audience, control and supply of bodies, etc.

It seems clear that the construction of permanent anatomical theatres in sixteenthcentury Europe was a response to the need for appropriate places for the performance of anatomical dissections in the presence of an increasingly numerous audience. There were various reasons for a higher attendance at dissections, ${ }^{5}$ but the most important was undoubtedly the close connection that dissection had at that time with the teaching of medicine, and the growing number of medical students. There was, therefore, a pressing need for buildings specially designed for that purpose.

In analysing how the practical teaching of anatomy became established in both old and new universities, a number of influences must be considered. Political power at various levels - royal, municipal, and social, among others-as well as the demands of students, surgeons' guilds, colleges of doctors and university teachers could all contribute to decisions taken by the university authorities, and to the success or failure of particular undertakings. Another factor, much studied by historians of medicine, that should not be forgotten is the role that some professors played in establishing the practice of dissection and, therefore, in the construction of permanent anatomical theatres.

In the pages which follow, we will study the development of anatomy in four Castilian cities and in three cities of the Crown of Aragon. Salamanca, Valladolid and Alcalá were the site of the most important Castilian universities, while the fourth-Madrid—housed the Spanish Court from the middle of the sixteenth century, although it did not then have its own university. The three capitals of the peninsular territories of the Crown of Aragon, Valencia, Barcelona and Saragossa, were home to universities of a different type from those in Castile, since their foundation, financial support and organization were mainly municipal.

Unlike the estudis generals (universities) of the Crown of Aragon, the most important Castilian universities were not controlled by their respective municipal governments. Their internal structure was collegial (they followed the model of Salamanca) and the weight of royal power was more obviously felt in many of the decisions. On the other hand, their respective faculties of medicine continued to have only a minor role in university studies. The theologians, jurists and canonists at the various colleges of Salamanca, Alcalá and Valladolid always took precedence, and had most influence in the political networks established between these institutions and those of the monarchical government, and so attracted more students. Thus, the physicians and their professional aspirations remained in the background. It was in this competitive arena that the following events relating to the practical teaching of anatomy took place.

anatomy theatre of Bologna', Past and Present, 1987, 117: 50-106; L Wilson, 'William Harvey's Prelectiones: the performance of the body in the Renaissance theatre of anatomy', Representations, 1987, 17: 62-95; J Helm, 'Protestant and Catholic medicine in the sixteenth century? The case of Ingolstadt anatomy', Med. Hist., 2001, 45: 83-96; and C Klestinec, 'A history of anatomy theaters in sixteenth-century Padua', J. Hist. Med. Allied Sci., 2004, 59: 375-412.

${ }^{5}$ Many authors have considered this matter; for one point of view, see K Park, 'The criminal and the saintly body: autopsy and dissection in Renaissance Italy', Renaiss. Q., 1994, 47: 1-33, pp. 14-18. 


\section{Àlvar Martínez-Vidal and José Pardo-Tomás}

\section{Valladolid}

In 1611 the Senate of the University of Valladolid debated whether to provide its Faculty of Medicine with a professorship of anatomy. Among the people consulted, was Luis Mercado (1525-1611), who, although retired, had been the most important medical figure in the previous decades and one of the most valued medical authors, renowned as much for his many printed works $^{6}$ as for his brilliant professional career. Mercado stated his opinion most emphatically: "Good medicine has been practised in Spain for more than two hundred years without any need to teach that discipline [anatomy] and in this country there is nobody sufficiently trained to practise it"?

If this authoritative pronouncement is to be believed, not only Valladolid but Spain as a whole presented a clear case of resistance to the introduction of the teaching of anatomy and the practice of dissection. The importance of such a figure as Mercado and the forcefulness of his statement only reinforce such an idea. Nevertheless, an isolated testimony, however important the person that expresses it, cannot be the basis for any general conclusion. In fact, Mercado's categorical statement is wholly false and must be understood within both the specific context of the debate on the reform of university studies at Valladolid at a crucial moment, and the framework of a cultural policy marked by the circumstances of that moment. While the result of the 1611 discussion seems to have gone against the teaching of anatomy, there were also some opponents of that decision. For instance, we know that in 1626 the students repeated their demands for classes in this subject. However, before this episode of 1611, things had been very different, in spite of what Mercado said.

Thus, it is worth recounting the early, and therefore interesting, incident in which Alonso Rodríguez de Guevara ( $f l$. 1540-1580), a surgeon at that time, took part. He taught anatomy on the body at the University of Valladolid from 1548 to 1550, and he had an immense influence not only among students, but also among teachers and the physicians of the Court, which in those days still used to stay for long periods of time in that Castilian city. ${ }^{8}$

In his work on anatomy, published in Portugal in 1559 and dedicated specifically to refuting some aspects of Vesalius's Fabrica, ${ }^{9}$ Rodríguez de Guevara stated that, as a result

\footnotetext{
${ }^{6}$ A total of 37 editions of various medical works by Luis Mercado were published between 1574 and 1650 . For a complete list of his published work, see J M López Piñero, et al., Bibliographia Medica Hispanica 1478-1950, Valencia, Instituto de Estudios Documentales e Históricos sobre la Ciencia, 1987-1989, vol. 1, pp. 139-47 and vol. 2, pp. $170-5$.

7 "En España se ha hecho buena medicina durante más de doscientos años sin necesidad de tal disciplina [anatomía] y no existen en el país personas lo suficientemente preparadas para su práctica". Archivo de la Universidad de Valladolid (hereafter AUV), Libro 6 de Claustros, fol. 140v-1. Quoted in A Rojo, Medicina barroca vallisoletana. Antonio Ponce
}

de Santa Cruz y Alfonso de Santa Cruz, Universidad de Valladolid, 1984, p. 26. This is Mercado's most important allusion to the development of the teaching of anatomy at the University of Valladolid at the time we are dealing with and introduces many of the sources on which our article is based.

${ }^{8}$ López Piñero, op. cit., note 3 above, pp. 97-100.

${ }^{9}$ Rodríguez de Guevara's professional career in Portugal can be linked to the establishment of a new academy Physico Chirurgica at All Saints' Hospital of Coimbra. See M Lemos, História da medicina em Portugal: doutrinas e intituiçoes, Lisboa, Publicações Dom Quixote, 1991, vol. 1, pp. 147-57. 


\section{Anatomical Theatres in Early Modern Spain}

of his work, the University of Valladolid was provided with a chair of anatomy. ${ }^{10}$ In spite of the lack of documentary evidence, ${ }^{11}$ we know that such a chair must have existed at this university during most of the second half of the sixteenth century and that its last occupant was Pedro de Sosa. ${ }^{12}$ However, from 1592, the professorship of anatomy was changed to one of Method, coinciding with Sosa's promotion to the chair of Prima precisely because of the all-powerful Luis Mercado's retirement. ${ }^{13}$

Nevertheless, two points should be made. Only two years after the disappearance of the professorship of anatomy, one of surgery was created-consequently anatomical knowledge must have been an important requirement. The chair of surgery was established at the request of the Crown because of the need to have Castilian surgeons educated for the royal service. ${ }^{14}$ In addition, in 1597, as a consequence of the ravages of an epidemic of plague and the medical shortcomings that it exposed, there was a reaction against the abolition of the chair of anatomy, which had occurred five years earlier, and a debate ensued about the need to reinstate it. ${ }^{15}$

The existence of both the anatomy and surgery professorships in the first decades of the seventeenth century was extremely precarious. The events of 1611 and 1626 confirm that there was a conflict between those who supported both the professorships and those who defended the majority view that opposed the practice of anatomy as part of the medical teaching at Valladolid.

\footnotetext{
${ }^{10}$ A Rodríguez de Guevara, In Pluribus ex iis quibus Galenus impugnatur ab Andrea Vesalio Bruxelensi in constructione et usu partium corporis humani, Coimbra, apud Ioannem Barrerium, 1559, "Ad candidum lectores", pages unnumbered. The translation into Spanish of this interesting passage appears in A Hernández Morejón, Historia

bibliográfica de la medicina española, 7 vols, Madrid, Imprenta de la Viuda de Jordán e hijos, 1842-52, vol. 3, pp. 87-92, on p. 89: “The University of Valladolid was most justly provided with a professorship. When sixty days had passed (in spite of the great number of scholarly competitors that had gathered there as if by chance), without the students being consulted, I was solemnly appointed to it"; "se instaló con no poco auxilio de la justicia, una cátedra en la Universidad de Valladolid, la que después de pasados sesenta días (a pesar del gran número de sábios competidores que allí como por casualidad se habían reunido), sin tomar ningún parecer a los estudiantes, me fué encargada solemnemente").

${ }^{11} \mathrm{M}$ Alcocer, Historia de la Universidad de Valladolid. Bio-bibliografías de médicos notables, 7 vols, Valencia, 1931. No mention is made in this work of any professors being appointed to the chair at this time.

${ }^{12}$ This is evident from the payments entered in the University account books consulted by Rojo, op. cit., note 7 above, p. 13

${ }^{13}$ As Rojo indicates, we do not know whether, while he was professor of anatomy, Sosa's teaching
}

included the practice of dissections, since "a more thorough search of the University of Valladolid archives" remains to be done. ("una más concienzuda revisión de los fondos del Archivo de la Universidad de Valladolid"): Rojo, op. cit., note 7 above, p. 22.

${ }^{14}$ The Crown's reasons for promoting the establishment of a professorship are clearly set out in the royal provision of 20 Dec. 1553, "so that there are learned men at that faculty ... from among whom we can choose enough men for our service, who would have the title of royal surgeons" ("que aya hombres doctos en esa facultad ... de donde elijamos hombres suficientes para nuestro servicio y que los tales tengan título de cirujanos regios"). AUV, Libro 4 de Claustros, fol. 286v-7r. Quoted in Rojo, op. cit., note 7 above, p. 17

${ }^{15}$ The physicians of Valladolid requested the vice-chancellor to consider "whether it would be convenient, in such occasions of illness, [that there should be] a professorship of Anatomy at this University from then on ... since it used to exist in the old days ... and there is one now at Salamanca"; ("si convendría para ocasiones semejantes de la enfermedad [que] de aquí en adelante en esta Universidad [hubiera] una cátedra de anatomía. . pues antiguamente la solía haver ... y la ay en Salamanca"). AUV, Libro 5 de Claustros, fol. 34v. Quoted in Rojo, op. cit., note 7 above, p. 21. 


\section{Àlvar Martínez-Vidal and José Pardo-Tomás}

Therefore, to come full circle, Mercado's statement is false, whichever way it is looked at. If he felt obliged to exaggerate the contempt in which anatomy was held by the school of Valladolid, it was not because dissection had not been practised in two centuries, but rather because he reacted angrily to pressure from the Senate, which demanded that anatomies be performed again. Despite this pressure, everything seems to indicate that during most of the seventeenth century, physicians studying at the Faculty of Medicine of Valladolid received no training in anatomy. It is, therefore, not at all surprising that no documents have so far been found relating to any permanent and specific "places of anatomy" in that Castilian city.

\section{Salamanca}

As regards the first and oldest Castilian university, that of Salamanca, the situation was very different, since at a very early date it did create a specific site for the practice of anatomy with an educational purpose. The permanent anatomical theatre of the University of Salamanca is the oldest in Spain and perhaps in Europe, since it was ordered to be built in June 1552 and was finished in May 1554. ${ }^{16}$

In order to understand why the anatomical theatre was constructed, two matters have to be taken into account: the so-called "Vesalian reform" movement in Spain; ${ }^{17}$ and a particular "cultural policy" related to the teaching and the practice of medicine, initiated by the government of Charles V (1516-1556) and continued by that of his son, Philip II. As far as the first is concerned, it must be remembered that the teaching of anatomy at Salamanca started in September 1551 with dissections initiated by Cosme de Medina (d. 1591). Medina was an important figure, well informed about the Vesalian reform movement, who had been the co-worker of Luis Collado (c. 1520-1589) in the dissections Collado had performed during his Valencia professorship. Following Vesalius's assumptions, Medina introduced a form of practical teaching in Salamanca that gave people such as the Catalan Francesc Micó (1528-post 1582) the opportunity to acquire a sound anatomical education. It was Micó who introduced the new anatomy to the royal hospitals of the Monastery of Guadalupe in the $1560 \mathrm{~s}^{18}$ and to the Estudi General (university) of Barcelona in the following decade.

With regard to the "cultural policy", it is very significant that it was the direct intervention of royal authority, through the Council of Castile, which launched the teaching of anatomy and the practice of dissections. Thus, in 1550, the Council ordered the University of Salamanca to deliberate "on Anatomy, since Their Majesties [Charles V and Queen Joan] command the Council to study and discuss whether it would be convenient and profitable to perform anatomies in these kingdoms". ${ }^{19}$ The University sent a favourable reply: "once the contents of the said royal proposal had been discussed and deliberated,

\footnotetext{
${ }^{16} \mathrm{~T}$ Santander, 'La iglesia de San Nicolás y el antiguo teatro anatómico de la Universidad de Salamanca', Revista Española de Teología, 1983, 43: 253-73, pp. 257-9. This article contains the essential documentary sources on the establishment of the anatomical theatre of Salamanca.

${ }^{17}$ López Piñero, op. cit., note 3 above. This is still the best account of this matter.
}

\footnotetext{
${ }^{18}$ Ibid., pp. 69-70. From the fifteenth century, the royal hospitals of Guadalupe were the most important centre for training royal surgeons and physicians in Castile.

${ }^{19}$ Archivo de la Universidad de Salamanca (AUS), 18, fol. 120v. Quoted in Santander, op. cit., note 16 above, p. $256 \mathrm{ftn} 22$ : “çerca de la anatomía que sus magestades [Charles V and Queen Joan] mandan que se
} 


\section{Anatomical Theatres in Early Modern Spain}

most physicians and surgeons considered that the practice of anatomies would be very advisable, beneficial and necessary". ${ }^{20}$

Cosme de Medina's presence at the University of Salamanca, where he lectured in anatomy and practised dissections from September 1551, should be seen as a result of this decision. The professorship of anatomy was created then, and provided with 40,000 maravedies annually, although the actual funds were not forthcoming until March 1552.

During those initial months, the dissections were performed at an improvised theatre built for this purpose in the corridors of the Escuelas Mayores, where benches and wooden seats were installed for the audience. ${ }^{21}$ What was made, therefore, was a theatre that could be dismantled, such as those being installed at the time in some other places such as Padua. The result of this first experience was clearly very positive, as shown in the understandable enthusiasm-almost excessive with regard to the number of bodies and their predicted availability — which can be detected in the resolutions of March 1552. The same document that contains Medina's appointment to the professorship of anatomy, also stipulates that "he must perform, at least, thirty anatomies a year, on human bodies or on other carcases, and if more corpses are provided, the more anatomies he should perform". ${ }^{22}$ However, from our point of view, the most important consequence of this enthusiasm was that it led to the decision of the academic authorities of Salamanca to build a specific and permanent place in which to practise anatomical dissections.

In the very same month, March 1552, an order was issued urging the vice-chancellor, the university treasurer and Luis Alderete (lecturer in Prima de Medicina) to "look for and choose the place where anatomies could be performed". ${ }^{23}$ Three months later, on 23 June, the place was located and a commission of three lecturers (Luis Pérez, of Canones, Alderete, and Cosme de Medina) was set up in order to "arrange for the building to be constructed next to Saint Nicholas' church" and they had at their disposal "all the maravedies that they need from the accountant of the Estudio". ${ }^{24}$

As a consequence, work on the theatre was finished on 5 May 1554 and Alderete reported to the University on the cost, a little less than 50,000 maravedies; in other words, a little more than the annual salary of a university professor. In addition, this document contains some details of the building's features, although none about either its size or shape. ${ }^{25}$ The theatre was located, as already mentioned, near Saint Nicholas' church and its cemetery. It must have had crude stone walls ("twenty-one cartloads of tuff stone" are indicated) and a slate roof, with its six correspondent beams. Almost half the money was spent on these materials. The other half was used for wood for the flooring,

vea e confiera si será cosa provechosa que se aga en estos reinos".

${ }^{20}$ Ibid., pp. 256-7: "aviendo entre si conferido e platicado sobre lo contenido en la dicha provisión real, a la mayor parte de los medicos e çirujanos paresçió cosa muy conveniente e provechosa e neçesaria que la dicha anatomía se aga".

${ }^{21}$ AUS, 20, fol. 71v-73v. Quoted in Santander, op. cit., note 16 above, p. 257.

${ }^{22}$ Ibid., p. 257: "por lo menos haga en cada un año anathomía en treinta cuerpos umanos, o en otros en su lugar, e que si más cuerpos le dieren que en más lo haga".

${ }^{23}$ Ibid.: "vean y señalen el lugar adonde se podrá haçer el egerçiçio de la anathomía".

${ }^{24}$ Ibid., p. 258: “... que agan açer el edeficio en el lugar donde se açer la dicha anotomía, junto a San Nicolás, e que para el dicho edefiçio todos los maravedís que fueren neçessarios los puedan librar e libren en el açedor del dicho Estudio."

${ }^{25}$ AUS, 1247, Book of general accounts, 1554-1557, fol. 216-218. Cf. Santander, op. cit., note 16 above, p. 258. 


\section{Àlvar Martínez-Vidal and José Pardo-Tomás}

benches and probably panelling, since five cartloads of 69 dozen planks, as well as three cartloads of "quartones", 12 small beams (possibly for the erection of some stands) and 10 "frame quartones" (perhaps for the door and windows) were listed in the accounts. Nothing is said, however, about the dissection table.

During the winter of $1554-5$, the theatre must have started to work at full capacity. The continuity of the practice of dissections in the theatre seems to be beyond all doubt, although what exactly the consequences of de Medina's efforts were over the second half of the sixteenth century is not known.

The Statutes of 1561 specified dissection as compulsory, with six general anatomies of a complete body being performed "in the house of Anatomy, built for that purpose" and the "twelve particular partial anatomies, either in the hospital of the Estudio or in the general hospital of Medicine", ${ }^{26}$ reducing to more realistic levels the excessive expectations fixed nine years before. Although in 1604 the professorship of anatomy was considered "outlandish and strange" by the Council of the Faculty of Medicine, the fundamental importance of anatomy ("most necessary for physicians") was insisted on, and we know that the professorship was occupied all that time by Diego Ruiz Ochoa, who gave up the position in 1607. Domingo Vázquez Mejía succeeded him, remaining in the post until 1611. Then, Alonso de Corrales held the chair until $1627 .^{27}$

There is evidence that indicates that dissections continued as normal during the first half of the seventeenth century, with the usual problems such as those of buying new instruments or applying for support from the authorities to use bodies from the city hospitals. ${ }^{28}$ However, those appointed to the professorship were either of little standing or in the early stages of their academic or professional careers, which in some instances would be notable. This is the case of both Fulgencio Benavente, a Valencian although educated at Salamanca, who lectured in anatomy from 1679 to 1681, and José Colmenero, who lectured from 1677 to $1678 .{ }^{29}$ Benavente became Philip V's royal physician, and Colmenero is well known for his work Reprobación del pernicioso abuso de los polvos de la corteza de el quarango o china-china (Salamanca, 1697), considered representative of the attitude of many Spanish Galenists, opposed to change and to almost everything foreign. ${ }^{30}$

Therefore, anatomical practice continued at the theatre of Salamanca, in spite of the problems that the Saint Nicholas chaplaincy and the church maintenance caused the University throughout the seventeenth century. These problems were due to the unfortunate location of the church, which directly affected religious practice, although it did not create any difficulties for the theatre or the activities that were carried out there, because they continued even after Saint Nicholas was closed in 1707.

The dissolution of the theatre is worth recounting briefly. Complaints about the position and the state of the building, and petitions urging the University to find a more suitable

\footnotetext{
${ }^{26}$ López Piñero, op. cit., note 3 above, p. 86: “en la casa de Anatomía edificada a este fin"; "las doze particulares o en el hospital del estudio, o en el de general de Medicina".

${ }^{27}$ L E Rodríguez-San Pedro Bezares, La Universidad salmantina del barroco, periodo 1598-1625, 3 vols, Ediciones Universidad de Salamanca, 1986, vol. 2, pp. 134-7.
}

\footnotetext{
${ }^{28}$ Ibid., pp. 535-46.

${ }^{29} \mathrm{~T}$ Santander, El Hospital del Estudio (Asistencia y hospitalidad de la Universidad de Salamanca) 1413-1810, Salamanca, CSIC, 1993, pp. $148-9$.

${ }^{30} \mathrm{~J}$ M López Piñero, Ciencia y técnica en la sociedad española de los siglos XVI y XVII, Barcelona, Labor Universitaria, 1979, pp. 394-5.
} 


\title{
Anatomical Theatres in Early Modern Spain
}

location increased in the first third of the eighteenth century. However, the judgement made in 1727, as a consequence of one of these petitions, appeared conclusive: "[although] the hermitage and the chapel are almost in ruins ... the theatre is in good enough condition for the said anatomies to be performed there as they are necessary and essential". 31

It was not until the process of university reform, initiated in 1771, that the decision to change the place where the dissections were performed was taken. Unfortunately, its relocation resulted in the demolition of the whole complex in 1801. Thus any traces of what may have been the first permanent anatomical theatre in Spain and one of the first in Europe disappeared.

\begin{abstract}
Alcalá
The first steps to establish the University of Alcala at the beginning of the sixteenth century were taken by Cardinal Cisneros at the instigation of the Crown. The University was organized along collegial lines in certain respects similar to that of Salamanca. Medicine was taught almost from the first and two professorships were provided. Nevertheless, the discipline always took second place to the studies of Theology and Canones. Even so, the prestige of the arts studies, due to the influence of well-known figures, such as Elio Antonio de Nebrija (1444-1522), and the royal insistence on providing Alcalá with professors of recognized scientific standing, gave special prominence to a whole generation of physicians educated at this University, who became important in medical circles in Renaissance Spain.

It is in this light that Pedro Jimeno's ( $f l$. 1515-1555) move to the University at the beginning of the 1550s should be seen. Jimeno came from Valencia, where he had been one of the prominent supporters of the assimilation of Vesalian anatomy by the Valencian Estudi General. Although the exact year in which the University of Alcalá was provided with a professorship of anatomy is unknown, undoubtedly Jimeno's arrival gave the final impetus required. Thus, it is not strange that a royal licence to dissect the bodies of executed criminals and those of people who died in the city hospitals was promulgated in 1559, nor that Pedro Marcos, also from Valencia, was appointed to the professorship of anatomy in $1563 .^{32}$ At present, there is no information about the site where these dissections took place, although it is reasonable to think that they were performed at some of the three hospitals of Alcalá (San Lucas, Altozana, and San Juan de Dios). ${ }^{33}$ During the following years, some other "outsiders" probably from Valencia as well, such as Valero Tobar in 1571 and Miguel Ferri in 1573 held the position.

In November 1574, for the first time, there were problems in finding someone to hold the professorship. In the following decade, it passed once again to Valencians, the physicians Jacobo de Salar (1583) and José Gutiérrez (1585-1591). Pedro Valverde, the next occupant

\footnotetext{
${ }^{31}$ Santander, op. cit., note 16 above, p. 265. "[aunque] la hermita y capilla está mui derrotada y descompuesta, ... el teatro anothómico está bueno para esenziales y prezisas".

${ }^{32}$ López Piñero, op. cit., note 3, pp. 86-8. The available documentation on the professorships of medicine at the University of Alcalá is still that found
} poderse hazer dichas anothomías, las que son mui

\author{
in L Alonso Muñoyerro, 'Provisión de cátedras y \\ catedráticos de medicina en Alcalá de Henares \\ (1509-1641)', in X Congreso Internacional de \\ Historia de la Medicina. Libro de Actas, Madrid, \\ 1935, vol. 1, fasc II, pp. 75-179; and La Facultad \\ de Medicina en la Universidad de Alcalá de \\ Henares, Madrid, CSIC, 1945. \\ ${ }^{33}$ Alonso Muñoyerro, op. cit., note 32 above, p. 36.
}




\section{Àlvar Martínez-Vidal and José Pardo-Tomás}

of the chair, was the first professor for whom there is evidence that he had been educated at the University of Alcalá itself. He was still professor of anatomy in 1597, when he also took charge of the professorship of surgery, created in 1574. In 1603, after six years during which there were again difficulties in finding a candidate, the post fell once more into the hands of a Valencian physician, Doctor Bardos. A document of 1614 explicitly acknowledges that there are problems in filling both the surgery and the anatomy chairs. It also states that these usually "go together", that is to say, that the same professor lectured in both subjects. In the same year, another "outsider" with a probable Valencian surname, Pedro Ferriol, took charge of them. Later, Pedro Miguel de Heredia (c. 1580-1655), educated at Alcalá, who would become very important over the following years, held the professorship until 1621. Marcelino Ubert Balaguer, from Saragossa, began to lecture in the discipline in 1625. Another "outsider", Juan Luis de Juneda, succeeded him in 1627, but left in the following year and it seems that the chair remained vacant, at least until $1641 .^{34}$

After this date, there is no evidence whether a further appointment was made. However, the text of García Medrano's reforms, published in 1665 and addressed to the whole of the University of Alcalá, stipulated that medical students had to take a two-year course in anatomy during which the partial anatomies and anatomies of the complete body, ten in total, as laid down in the statutes, had to be performed during the two years and that the other professors of the faculty were required to attend the classes. They also stated that the chairs of surgery and of anatomy were to be held jointly, "because there were not enough candidates for each of the professorships". ${ }^{35}$ But no mention was made of the place where these dissections were performed.

During this period, it was well known that the teaching of anatomy at the University of Alcalá had fallen into decay, even to the point that some travellers mentioned it in their writings. For instance, Lorenzo Magalotti (1637-1712), a member of the Duke of Tuscany's retinue, commented: "the whole of literature in Spain at present boils down to scholastic theology and outdated medicine as found in the works of Galen.... To prove this it is sufficient to tell you that in Alcalá-I beg you, Your Excellency, to mark this - in that celebrated and renowned institution, they have not taught anatomy for the last eight or ten years". 36

Although such sources must be treated with caution, since they at times repeat stereotyped commonplaces, in this case the words ring true. Magalotti travelled round Spain between 1668 and 1669. He was educated by the Jesuits in Rome and, afterwards by Malpighi and Borelli, among others. Given the problems with the teaching of anatomy at the University of Alcalá, Magalotti's assertion that in 1669 no dissections had been performed for eight or ten years is not surprising.

This situation regarding anatomical studies at Alcalá is key to understanding why Charles II (1665-1700) wished to establish at court, that is to say, in Madrid (very close to Alcalá), the teaching of anatomy by physicians and surgeons in an extra-university context.

\footnotetext{
${ }^{34}$ Ibid., pp. 81-6 and 186-90.

${ }^{35}$ Ibid., pp. 95-6: “. . . . andaba junta ... no haviendo opositor para cada una de la Cátedras”.

${ }^{36}$ Quoted in H Kamen, Spain in the later seventeenth century, 1665-1700, London, Longman, 1980, p. 313. Spanish ed., La España de Carlos II,
}

Barcelona, Crítica, 1981, p. 498. In our opinion, Magalotti does not place this in its correct context. For Magalotti's text, see "Relazione del viaggio di Spagna”: travels of Cosmo III, Grand Duke of Tuscany, through England during the reign of King Charles II (1669), London, J Mawman, 1821. 


\section{Madrid}

Until recently, the historiography has ignored the foundation of a professorship and the construction of an anatomical theatre in the General Hospital of Madrid in 1689. Both these events have traditionally been attributed to the arrival of the new Bourbon dynasty to the Spanish throne after the death of Charles II in November $1700 .{ }^{37}$ However, documents recently come to light show that the chair of anatomy and the Madrid anatomy theatre were part of the movement of reform in Spanish medicine that gained strength in the last quarter of the seventeenth century, one of whose most important centres was the court of Charles II. ${ }^{38}$

There was a first attempt by the Crown to establish a professorship of anatomy as early as 1684. This had the support of the Protomedicato's Court, ${ }^{39}$ the Castilian institution which regulated some aspects of medical practice, above all the licensing of physicians and other medical practitioners. In fact, a decision had even been taken as to who should be in charge of teaching and that the General Hospital should be the location for the anatomies. Given that the universities of the Crown of Aragon tended to favour anatomy as a part of medical education, it is not surprising that a search was made by the Crown among medical men who had been educated at one of them. Thus, the person finally chosen, in 1684, was a Catalan, Francesc Feu (c. 1640-1697).

However, initially, there was opposition from some quarters. One problem in particular that the hospital was not willing to resolve was that of economic support. Nevertheless, the Crown's interest resulted in funds being made available from the royal coffers. That is how, according to a royal decree of appointments dated 17 May 1689, Feu received the "house and other emoluments that correspond to the ancient positions of the twelve [physicians] of the House of Burgundy, because he holds this special and supernumerary position". ${ }^{40}$

The Protomedicato had advised the King that "public anatomies", performed by a "skilful anatomist", should be offered at Court. But in addition, it was laid down that one dissection a week must be performed throughout the seven months between 1 October and the end of April, making a total of more than twenty. Finally, the Protomedicato insisted that the professor's lecture should be addressed to both surgeons and physicians, and that the dissections could also be watched by "whoever else attended". ${ }^{41}$ This indicated the open nature of the anatomical display in a public place, in accordance with practice in other European cities at the time. ${ }^{42}$

\footnotetext{
${ }^{37}$ For a discussion of this and what follows, see J Pardo-Tomás, À Martínez-Vidal, 'Los orígenes del teatro anatómico de Madrid (1689-1728)', Asclepio, 1997, 49: 5-38.

${ }^{38}$ On this process, known as the novator movement, see López Piñero, op. cit., note 30 above, pp. 387-433; and more recently, À Martínez-Vidal, J Pardo-Tomás, 'In tenebris adhuc versantes. La respuesta de los novatores españoles a la invectiva de Pierre Régis', Dynamis, 1995, 15: 301-40.

${ }^{39}$ J Pardo-Tomás, À Martínez-Vidal, 'El tribunal del Protomedicato y los médicos reales
}

(1665-1724): entre la gracia real y la carrera profesional', Dynamis, 1996, 16: 59-89.

${ }^{40}$ Archivo General de Palacio, Madrid (hereafter, AGP), Sección Administrativa, box 12061, file 2: "gajes, casa de aposento y demás emolumentos que corresponden a la plaza de los doze [médicos] más antiguos de la Casa de Borgoña, como plaza especial y supernumeraria".

${ }^{41}$ All this appears in the Protomedicato's report of 2 April 1689: AGP, Sección Administrativa, box 12061, file 2 .

${ }^{42}$ For further discussion of this, see, for instance, A Gallassi, 'Malpighi e la funzione pubblica 


\section{Àlvar Martínez-Vidal and José Pardo-Tomás}

It was therefore essential to have a suitable place in Madrid and in the environs of the hospital where anatomical dissections could be performed and a large audience accommodated. In other words, what was required was an anatomical theatre like those being constructed in other European cities and courts at the time, or built for some Italian, Spanish and French universities during the previous century. In fact, in April 1689, a month before Feu's definitive appointment, the Protomedicato advised the king of "the need for an anatomical theatre or some other place where the physicians, surgeons and the rest of the audience can comfortably watch the dissections". ${ }^{43}$

Although everything seems to indicate that the theatre was built-either during Feu's tenure, which lasted until his death in 1697, or during that of his successor, the Valencian Roque Buendía, who lectured for the five following years-at present there is no clear documentary evidence of the exact year when the Madrid anatomical theatre was constructed. However, there is no doubt that the teaching and practice of dissection continued throughout this period. ${ }^{44}$

For an idea of what the Madrid anatomical theatre looked like in the early eighteenth century, there is the invaluable evidence of one of Matías de Irala's engravings, ${ }^{45}$ drawn for the Anatomía completa del hombre $(1728)^{46}$ by Martín Martínez (1684-1734). This book provides some information about the practices at the theatre in the years preceding its publication, and about the teaching materials that Martínez had at his disposal for the classes he gave, first as José Arboleda's ( $f l$. 1698-1728) substitute and afterwards as holder of the chair.

Irala's illustration shows an anatomical dissection being performed (see Figure 1). Through an entrance arch, carrying the inscription Amphitheatrum Matritense, we see a large square room with a high roof and a large window at the back. However, the light that illuminates the scene pours through an open window at the top of the left hand wall. At the top of the right hand wall, a female figure is leaning over a balcony or box which has a door to the outside. The animated audience of about twenty people is seated on a stand of two or three tiers, occupying three of the sides. It looks as if more people could be accommodated. A person placed on the left, who could be Matías de Irala himself, is drawing on a board. The professor, in an armchair placed between the stands, presides over the scene. In the foreground, in centre of the hall, is the dissection table with the corpse, and at its feet the figure of the dissector on a platform with his back to us. A central pedestal supports the rectangular table. Smoke rises from a receptacle on the right under the table, in which undoubtedly aromatic substances are burning. To the left of the pedestal, a tall wide-necked

dell'anatomia a Bologna', Rivista di storia delle scienze mediche e naturali, 1950, 41 (suppl.): 7-28; and Ferrari, op. cit., note 4 above; Gelfand, op. cit., note 1 above; and J C C Rupp, 'Matters of life and death: the social and cultural conditions of the rise of anatomical theatres, with special reference to seventeenth century Holland', Hist. Sci., 1990, 28: $263-87$.

${ }^{43}$ AGP, Sección Administrativa, box 12061, file 2: "se necesita de sitio o teatro anathómico donde puedan cómodamente ver las disecciones los médicos, los cirujanos y las demás personas que asistan".

\footnotetext{
${ }^{44}$ For a more extensive discussion, see Pardo-Tomás, Martínez-Vidal, op. cit., note 37 above.

${ }^{45}$ On Irala's anatomical engravings, see J M López Piñero, F Jerez Moliner, 'Clásicos españoles de la ilustración morfológica. III. La anatomía completa del hombre (1728), de Martín Martínez', Archivo Español de Morfología, 1996, 1: 119-25.

${ }^{46}$ M Martínez, Anatomía completa del hombre, con todos los hallazgos, nuevas doctrinas y observaciones ... según el méthodo con que se explica en nuestro Theatro de Madrid, Madrid, Bernardo Peralta for P del Castillo, 1728, frontispiece.
} 


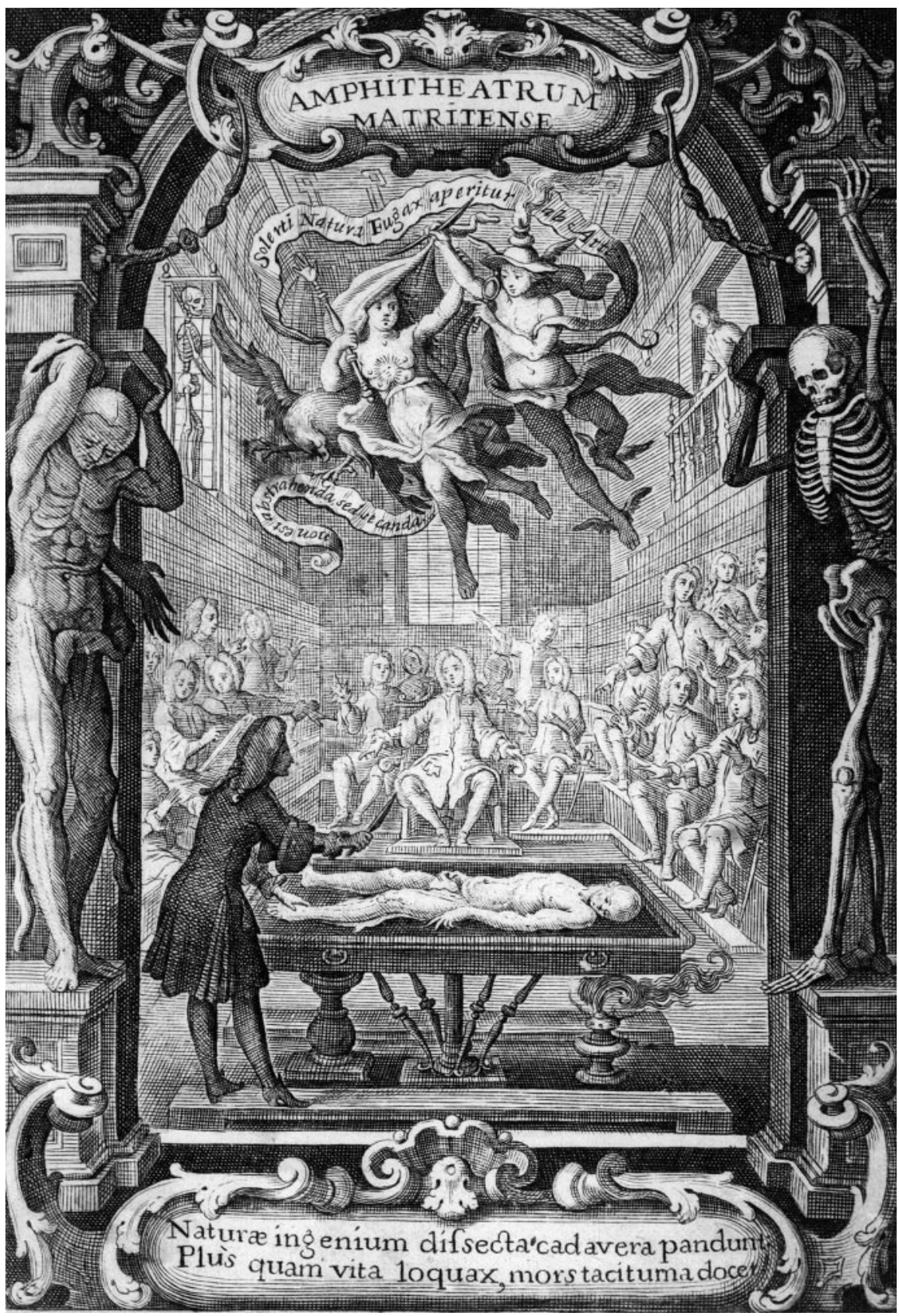

Figure 1: The Madrid anatomy theatre, engraving by Matías de Irala, from Martín Martínez's Anatomía completa del hombre, Madrid, 1728. Courtesy of the Biblioteca y Museo historicomédicos del Instituto López Piñero de Historia de la Ciencia y Documentación (CSIC/ Universitat de València). 


\section{Àlvar Martínez-Vidal and José Pardo-Tomás}

vessel reaches up to the lower side of the table, probably to catch the body fluids, which drain through a hole in the table.

With regard to the teaching materials that the theatre had at its disposal, in the engraver's image, a skeleton in a sort of cage can be seen at the top of the left hand wall. Martínez himself refers to the existence of an "artificial skeleton ... that is in our Theatre and that I will use to explain Osteology". ${ }^{47} \mathrm{He}$ also alludes to the existence of pictures and tables with the same didactic purpose. To be precise, he refers to a table that illustrates the distribution in layers of the walls of the artery. ${ }^{48}$ However, it does not seem likely that Madrid's theatre had at its disposal any anatomical wax preparations at the time since, when describing them and defending their pedagogical usefulness, Martínez only points out the existence of such devices in other countries. ${ }^{49}$

\section{Valencia}

The beginnings of the Valencian anatomical tradition date from 1478, when the Col-legi de Barbers $i$ Cirurgians (College of Barbers and Surgeons) acquired the royal privilege to dissect human bodies at the Estudi de Cirurgia (School of Surgery). ${ }^{50}$ Three years after this concession, in August 1481, the guild asked the king for either a "house or a garden" in which they could "perform the art of Anatomy". 51

It is not known whether the king granted such a petition at that time, but the fact that the request was made by the College indicates its members were accustomed to carrying out dissections. We know, however, that the surgeons finally achieved their purpose, because in 1524 they had at their disposal a place in which to practise dissections in the "yard" of the city's General Hospital. ${ }^{52}$

47 ،... Esqueleto artificial ... que se tiene en nuestro Theatro, y en quien explicaré la Osteología", ibid., p. 517.

${ }^{48}$ Ibid., p. 22: "The artery consists of four tunics, as has been proved and shown on a Board at our Theatre of Madrid, which are very evident when one sees the large vessels, but in the small blood vessels they are indivisible since they are very delicate"; ("La arteria consta de quatro túnicas según está demonstrado, y expuesto en una Tabla en nuestro Theatro de Madrid, las quales son muy manifiestas en los grandes troncos; pero en los pequeños vasos, por ser muy delicadas, son indivisibles").

${ }^{49}$ Ibid., p. 2: "since Art has found the way to represent in wax, with the required size and colouring, all the entrails contained in the three cavities, the structure of the muscles, the distribution of arteries and veins, and the rest of the parts of our body, as is the custom in other countries"; ("... aviendo hallado el Arte modo de representar sobre cera con el justo reliebe y colorido todas las entrañas contenidas en las tres cavidades, la fábrica de los músculos, la distribución de arterias, y venas, y demás partes de nuestro cuerpo, como se acostumbra en otros Países").

\footnotetext{
${ }^{50}$ The Estudi de Cirurgia existed in Valencia from
} 1462. The text of the privilege appears in L García Ballester, 'La cirugía en la Valencia del s. XV. El privilegio para disecar cadáveres de 1478', Cuadernos de Historia de la Medicina Española, 1967, 6: 155-71.

${ }^{51}$ Arxiu del Col-legi del Corpus Christi, València, Protocols notarials, Joan del Mas $n^{\circ} 27373,28$ August 1481. Quoted from M Gallent Marco, 'El colegio de barberos y cirujanos de Valencia: aportación documental', Saitabi, 1993, 43: 147-55, p. 154: "since we do not have even a suitable place to perform the art of anatomy, although we have a royal privilege, granted by the king, it is necessary for us to have at our disposal a house or garden, that belongs to our college and is funded by the king, where such acts could be performed"; ("... per quant nosaltres no tenim ne loch destinat tal qual mester seria per fer exercir aquell arte de anotomia, del qual tenim previlegi de sa magestat real, seria e és cosa molt necesaria haver una casa o ort qui fos del nostre col.legi e mortizada per lo senyor rey, en la qual los dits actes se poguessen fer").

${ }^{52}$ M Gómez-Ferrer Lozano, Arquitectura y arquitectos en la Valencia del siglo XVI. El Hospital General y sus artifices, Valencia, Universitat de València, Doctoral Thesis (PhD), 1995, p. 729. 


\section{Anatomical Theatres in Early Modern Spain}

The University of Valencia became the centre from which the Vesalian reform movement spread throughout the Iberian peninsula in the sixteenth century. ${ }^{53}$ In 1501 , when university professors were appointed to the recently created Estudi General, one of the two medicine cadires (chairs) was assigned to the teaching of anatomy. The professor in charge of this cadira gave classes in anatomy during the cold months of autumn and winter. Undoubtedly, this professorship was the first to teach anatomy in the Hispanic kingdoms, and perhaps one of the first outside Italy. The teaching followed the theories of the Arab-influenced Galenism of the late Middle Ages.

However, the publication in 1537 of Miguel Juan Pascual's translation into Castilian of Giovanni da Vigo's Practica in arte chirurgica shows, by the glosses on the original text, that Berengario da Carpi's findings were well known in Valencia and that in his arguments the translator took into account his own experience of dissection. The most outstanding figures of the Valencian anatomical school were Pedro Jimeno, professor from 1547 to 1550 and author of the Dialogus (1549) and his immediate successor, Luis Collado, the author of De ossibus (1555). The Valencian school influenced both Alcalá and Salamanca, ${ }^{54}$ and indirectly the hospitals of the Monastery of Guadalupe. It also influenced Hispanic pathology and surgery through men such as the physician Francisco Valles and the surgeon Francisco Díaz. The separation in 1560 of the teaching of anatomy and medical botany into two independent chairs was a landmark in the acceptance of anatomy as a discipline in its own right. ${ }^{55}$

In the last third of the sixteenth century, anatomical studies in Valencia declined. The only published work was the Tratado de Anatomía (1580) by Juan Calvo, ${ }^{56}$ since there are no extant printed copies of the Anatomia by Vicente García Salat, who held the professorship for a large part of the last years of the sixteenth century and the beginning of seventeenth. During the first half of the seventeenth century, the scholastic oriented education of the Valencian physicians increased and at the same time the level of their scientific production fell.

In 1677, the professor of anatomy, Matías García, published a treatise condemning the theory of the circulation of the blood, describing it as an almost contagious poison that "could corrupt many true medical concepts". Nevertheless, despite this militant resistance to change, the practice of dissection in Valencia did not disappear, quite the opposite. Matías García, a representative of the most intransigent Galenism at the University of Valencia, tried to refute Harvey's doctrine by means of arguments based on his own

\footnotetext{
${ }^{53}$ J M López Piñero, 'Los saberes médicos y su enseñanza', in Historia de la medicina valenciana, 3 vols, Valencia, Vicente Garcia Editores, 1988, vol. 1, pp. 109-42.

${ }^{54}$ Escolano's much quoted remark confirms this: "[Anatomy] was not known in Castile until the Valencian people went to Salamanca and Alcalá to lecture on it" ("[la anatomía] ni la conocieron en Castilla hasta que fueron Valencianos a leerla en Salamanca y Alcalá"), in G Escolano, Década primera de la historia de la insigne, y coronada ciudad y reyno de Valencia, Valencia, Pedro Patricio Mey, 1610, pt. 1, bk 5, col. 1063.
}

\footnotetext{
${ }^{55}$ J M López Piñero, La Facultad de Medicina de Valencia (1502-2002): breve historia de medio milenio, Universitat de València, 2002, pp. 39-48.

${ }^{56}$ This treatise appears in a surgical text entitled Primera y segunda parte de la cirugía universal y particular del cuerpo humano (Sevilla, 1580), often reprinted afterwards. See J L Fresquet Febrer, 'El Tratado de anatomía (1580) de Juan Calvo. Contribución al estudio de la morfología postvesaliana española', in Estudios dedicados a Juan Peset Aleixandre, 3 vols, Universidad de Valencia, 1982, vol. 2, pp. 17-28.
} 


\section{Àlvar Martínez-Vidal and José Pardo-Tomás}

anatomical experience through innumerable autopsies and vivisections of different kinds of animals. As J M López Piñero points out, it is sadly ironic that the greatest exponent of the most intransigent Galenism had unconsciously assimilated his opponents' methods. ${ }^{57}$

The University regulations of 1651 gave legal sanction to the custom of paying for dissections over and above the eight that the previous constitutions had prescribed, and, as a result, the total number of dissections increased to twenty. ${ }^{58}$ In 1681, it was stipulated that the students had to pay for the practice "as well as for the knives, for the [sweet] smells, for the flowers and for having the corpses prepared for the dissection"; 59 and, in 1687, the year in which Matías García retired, Crisóstomo Martínez was sent to Paris, with a grant from the Consell Municipal, to continue working on his anatomical Atlas. ${ }^{60}$ Consequently, at the beginning of the eighteenth century, in spite of the vicissitudes of war, anatomical dissection was regularly practised within the university. The number of the dissections required by the university authorities increased once again in 1707 , from twenty to twentyfive, and the anatomy teacher's salary from 100 to 150 pounds. $^{61}$

It is significant that when, in 1728, Martín Martínez accused the Spanish universities of not practising anatomy, Vicent Gilabert, the Valencian physician who lived in Madrid, replied to his criticisms with an explicit defence of that of Valencia. In the prologue to his Escrutinio physico-medico-anatomico (1729), Gilabert stated that at that University "there is an expert professor of anatomy who is not cathedratico de anillo, he is very skilful and worthy of his university chair ... his official responsibility being to explain anatomy and perform twenty-five dissections for every course at the public anatomical Theatre that the city has built for this purpose in the General Hospital and so that there will be no lack of skilful dissectors. The authorities have had the foresight to keep eight students in the house to perform the anatomical dissections", 62

\footnotetext{
${ }^{57} \mathrm{~J}$ M López Piñero, et al., Diccionario histórico de la ciencia moderna en España, 2 vols, Barcelona, Península, 1983, vol. 1, pp. 371-2.

${ }^{58}$ On 30 July 1630, Francesc Miquel Febrer, holder of the professorship of anatomy, was granted an annual salary of 100 pounds, instead of the 50 he had earned until then, provided that he performed twenty dissections instead of the eight required by the regulations. A Felipo Orts, La Universidad de Valencia durante el siglo XVII (1611-1707), Valencia, Conselleria de Cultura, Educació i Ciència de la Generalitat Valenciana, 1991, pp. 43-4.

59 “. . . així per als ganivets com per a olors, flors i preparar lo cos per a les notomies". Arxiu Municipal de València, Manual de Consells 1680-81, A-212, 26 April 1681. This document was published by S García Martínez, 'La cátedra valenciana de anatomía durante el último tercio del siglo XVII', La medicina, la ciencia y la técnica en la historia valenciana, Valencia, Sociedad Española de Historia de la Medicina, Ayuntamiento de Valencia, 1971, p. 180.

${ }^{60} \mathrm{~J}$ M López Piñero, El atlas anatómico de Crisóstomo Martínez, 2nd ed., Ayuntamiento de Valencia, 1982.

${ }^{61}$ Felipo Orts, op. cit., note 58 above, p. 44. See also the document dated 1724 in which Juan Bautista
}

Longás, holder of the professorship of anatomy, is certified as having performed 25 anatomies-he needed this confirmation in order to receive his complete salary, without any penalties-in Bulas, constituciones y documentos de la Universidad de Valencia (1707-1724): la nueva planta y la devolución del patronato. Edición y estudio preliminar de M. Peset, M.F. Mancebo, J.L. Peset y A.M. Aguado, Secretariado de Publicaciones de la Universidad de Valencia, 1977, p. 325. The testimony given before the town clerk by "Joseph Allvé and Francisco La Sauca, medical students and anatomists" ("Joseph Allvé y Francisco La Sauca, Estudiantes de Medicina y Anotómicos") states that "they have listened to Dr Juan Sebastián Longás explaining twenty-five anatomies, and they know it because they were present, and, as anatomists, they have helped him to carry out the dissections of the bodies in each of the said anatomies". ("han oido explicar al dicho Dr. Juan Bautista Longás veinte y cinco Anotomías, lo que saben por averse hallado presentes, y como a tales Anotómicos aver executado cada uno respective la disección de los cadáveres en cada una de las dichas Anotomias".) 62 “... . ay Professor de Anatomía, tan experto en el punto Anatómico, que no es Cathedratico de Anillo, sí muy hábil y digníssimo de la Cáthedra que 


\section{Anatomical Theatres in Early Modern Spain}

It is clear that the place where the practice of dissection and the teaching of anatomy were carried out in Valencia was the General Hospital. However, information on the architectural features of the theatre, as well as its exact location within the hospital area, varies a great deal and is very vague. The oldest reference, provided by a document dated 1524, alludes to an irrigation ditch that flowed through the hospital grounds, next to the place where the surgeons had built a house to carry out anatomical dissections. ${ }^{63}$ María Luz López Terrada thinks that at the end of the sixteenth century, in 1586 precisely, there was in the hospital a caseta de notomies near the hen yard and the algepseria (plaster's store), where the dissections required under the University Ordinacions were performed. ${ }^{64}$ López Piñero, for his part, points out that the dissecting room was rebuilt in 1624 and enlarged in $1637 .^{65}$

In the Arxiu Històric Municipal of Valencia several documents dated 1714 comment on the poor state of the hospital's anatomy classroom at the time and on the request of the encumbent professor, Tomás Longás y Pascual, to erect a new theatre in the hospital area. The town councillors had an easy alternative - that of repairing the existing one-but they apparently preferred the professor's more expensive option, and agreed a budget of 200 pounds:

... Being necessary for the public weal that such an exercise [of Anatomy] could be performed and that the classroom be presentable and clean, since people of the first rank attended many of these events, he [Longás, in his memorial for the Town Council] concluded by asking that the aforementioned classroom be rebuilt in some other more suitable location within the Hospital, in order to avoid passing through the wards ... [now the commissioner of the University, Regidor Rivera i Borja reports] that it being compulsory for the Professor of Anatomy, according to the University regulations, to perform twenty-five anatomies a year ... the greatest precision is required because the wards for convalescence having recently been rebuilt these obstruct the entrance to said classroom ... Of course, it was agreed ... to build the classroom of Anatomy, using the profits from the taxes on wine for payment [an estimated cost of 200 pounds]. ${ }^{66}$

desfruta ... siendo su Instituto dar y explicar materias Anatómicas, y en cada Curso hazer 25 dissecciones en el Theatro público de Anatomía, que la Ciudad tiene erigido en el Hospital General, para este fin ... y assí para que no falten disectores hábiles, ay la providencia de tener la Casa de Anatomía ocho Estudiantes, dedicados para hazer las Dissecciones Anatómicas". V Gilabert, 'Prólogo', Escrutinio physico-medicoanatomico, Madrid, Imprenta de Gerónimo Roxo, 1729, unpaginated. "Cathedratico de Anillo" means literally a "professor who wears a ring". Bishops and other dignatories, such as holders of chairs, wore a ring of office, which showed that they did no manual work.

${ }^{63}$ Gómez-Ferrer Lozano, op. cit., note 52 above, p. 729.

${ }^{64}$ M L López Terrada, 'El Hospital General de Valencia en el siglo XVI (1512-1600)', Universidad de Valencia, Doctoral Thesis (PhD), 1987, p. 606. A document dated 1586, regarding the extension of the ward of mal de siment, points out that location. Arxiu de la Diputació de València, I-5.1/C-1, leg. 1: Declaraciones de Pere Carbonell ... sobre los capitulos de la Cofradía de Bellem y la obra de las enfermerías, quoted by M L López Terrada, 'El mal de siment en la Valencia del siglo XVI: imágenes del morbo gallico en una ciudad mediterránea europea', Dynamis, 1991, 11: 119-46, p. 123.

${ }^{65}$ López Piñero, op. cit., note 60 above, p. 31.

66 ،... siendo preciso para el bien público hubiese semejante exercicio [de la anatomía] y que el aula estubiese con la decencia que pedía y devía estar, por acudir a muchos actos personas de la primera distinción, [Longás] concluyó pidiendo [en su memorial al Ayuntamiento] se bolviese a reedificar la referida aula, y que fuese en otro paraje de dicho Hospital más proporcionado para obviar el que no se pasase por las quadras ... [informa ahora el Comisario de la Universidad, Regidor Rivera i Borja] que teniendo obligación el Cathedrático de Anotomía, según Constituciones de la Universidad, de hazer veinte y cinco anotomías cada un año ... lo que obliga a la maior precisión es el que haviéndose fabricado nuevamente unas quadras para la combalecencia, éstas impiden el ingreso en dicha aula ... Acordóse ... desde luego se 


\section{Àlvar Martínez-Vidal and José Pardo-Tomás}

This new building, located in the vicinity of the Casa de Locos (quarters for the insane), had a short life, since it was demolished at the end of the eighteenth century as a consequence of some building work carried out in the hospital. ${ }^{67}$

\section{Barcelona}

The establishment of a permanent anatomical theatre in Barcelona, according to the tripartite model that we are referring to-hospital, professionals, university-dated from 1573, when the city government - the Consell de Cent-decided to equip an outbuilding of the Hospital General de Santa Creu so that the physicians of the Estudi General could perform satisfactorily the anatomical dissections that the University regulations stipulated. Thus there was a close resemblance between the medical features of Barcelona and those of Valencia, which would very soon be adopted by Saragossa as well. These were: the existence of an anatomical tradition connected with the corporations of both the physicians and the surgeons; the creation of a university professorship of anatomy, at the same time as the setting up of medical faculties in university; and the presence of an important hospital in which to place the anatomical theatre where the dissections for primarily educational purposes in accordance with the regulations were performed. At this point, there existed in each of these three cities a coherent system conceived and set up by the respective urban élites; a system whose welfare activity, which included poor relief and training for the people responsible for the population's health, was organized by the municipality. This convergence of corporate, educational and welfare interests required a specific area dedicated to the practical teaching of anatomy, known as casa de anatomia (house of anatomy). ${ }^{68}$

The primitive anatomical theatre of Barcelona originated with the concordia signed between the University and the College of Doctors in Medicine in 1565, which marked the amalgamation of the recently created Faculty of Medicine with the pre-existent Estudi de Medicina. At first, the dissections were performed in a room in the University that soon proved inadequate for the task. For this reason, in 1573, the Consell de Cent was asked for an appropriate place where the annual dissections required under the university rules could be easily carried out. The place proposed was in the grounds of the Hospital de Santa Creu. ${ }^{69}$

haga el aula de Anotomía, valiéndose para su costo [calculado en 200 libras por el Regidor] de lo precedido de la sisa cargada sobre el vino". In the final agreement, signed on 11 Oct. 1714, the City Council pronounced in favour of the second option, that is, the construction of a new theatre. It is interesting that the report of Rivera i Borja, the hospital manager and treasurer, dated 2 September says of the existing classroom, that not only was it "almost ruined" ("mui derruida") and difficult to access, but also it was "such a little and extremely small place and not big enough to accommodate the many students that studied Medicine and the other people attending this practical teaching" ("... el sitio tan corto y sumamente redusido y no bastante para que quepan los muchos estudiantes que suelen cursar el General de Medesina, Médicos y Sirujanos y otras personas que asisten a esta práctica enseñansa"). See Bulas, op. cit., note 61 above, pp. $119-22$.

${ }^{67}$ C Císcar Vilata, 'El Hospital General de Valencia en el siglo XVIII (1700-1800): el edificio, el gobierno, el personal y la asistencia', Universitat de València, Doctoral Thesis (PhD), 1992, pp. 289-90.

${ }^{68}$ À Martínez-Vidal, J Pardo-Tomás, 'El primitivo teatro anatómico de Barcelona', Medicina e Historia (3 $3^{a}$ época), 1996, 65: 5-28.

${ }^{69}$ The professorship of anatomy at Barcelona in the first half of the century has been studied by A Fernández Luzón, 'La Facultad de Medicina de Barcelona (1559-1595)', Barcelona, Universitat Autònoma de 


\section{Anatomical Theatres in Early Modern Spain}

This request was apparently granted, since, at the beginning of the seventeenth century, the dissections that the University required were performed in a so-called aula de les anatomies located beside the corralet - the hospital cemetery-in the north-eastern area of the hospital precincts.

In 1638, the Consell de Cent decided to provide funds for improving the conditions of this classroom. ${ }^{70}$ This decision was connected with the requirement under the University Ordinacions of 1629 for apprentice surgeons to study anatomy for a year at the Estudi, which meant a qualitative leap in the education that the city demanded of their future surgeons. There arose, therefore, a problem of making room in the aula de les anatomies for the apprentice surgeons as well as for the students of medicine. ${ }^{71}$ The university regulations of 1629 expressly stipulated the need for the fitting out of a suitable place for the dissections in the hospital which would accommodate all who had to attend. ${ }^{72}$

Consequently, the inherent requirements of the surgeons' training gave new stimulus to the practical teaching of anatomy throughout the seventeenth century. This fact is worth stressing at least in the case of Barcelona, since it has commonly been believed that such practical teaching started with the Enlightenment ideas of the eighteenth century. But the reverse is true. The comment that the surgeons' training was essential to "the public benefit and the right policy of the Principality [of Catalonia]" was generally accepted around the middle of the seventeenth century. This is proved both by the report that Josep Vilar, ${ }^{73}$ the Estudi professor of surgery at the time, wrote in 1657, and by the nou redreç (new reform) that the College of Surgeons approved in $1658 .^{74}$

The renovation works approved in 1638 took several years (it would not be accurate to speak of the "construction" of the theatre as if it were a new building). The delay was due among other things to the social and economic instability caused by the rebellion of 1640 and the subsequent war. Nevertheless, it seems that anatomical activity continued and the idea of investing in the renovation was not forgotten by the various city institutions concerned: the municipal government, the university, and the hospital. Therefore, the administrators of the Hospital de Santa Creu decided, in November 1644, to resume the work approved six years earlier and asked the Consell for the 80 pounds needed

Barcelona, 1995, (unpublished Dissertation). We are grateful to Antonio Fernández for permitting us to consult the original text, as well as for his comments on our essay.

${ }^{70}$ A Cardoner, 'La construcción de un anfiteatro anatómico en Barcelona en el siglo XVII', Medicina Clínica, 1962, 37 (5): 389-90. The Hospital de Santa Creu was one of the places where anatomical dissections were traditionally performed and from 1488 a royal authorization was available, according to which they could use the bodies of those who died within the hospital. J M Roca, L'Estudi general de Lleida, Barcelona, s.d., p. 112.

${ }^{71}$ Arxiu Històric de la Ciutat de Barcelona (hereafter AHCB), Consell de Cent, Estudi General, XVIII-8, pp. 103-4. The regulations of 1629 had simply obliged the apprentice surgeons to study surgery for two years in the Estudi. Ordinacions e nou redrés feta per instauratió, reformatió e reparatió de la
Universitat del Studi General, Barcelona, Pere Lacavalleria, 1629, p. 103.

${ }^{72}$ Ibid., p. 56. A 1658 register of the College of Surgeons confirms that the statutes of 1638 were put into practice, since the surgeons who wanted to take the examination for registration in this College were required to present their University certificates. AHCB, Gremis, XI-2, 'Ordinacions del nou redreç del collegi dels cirurgians'.

73 ، ... la utilidad pública y buena política del Principado". The phrase in quotes belongs to Josep Vilar's report, printed in January 1657, where he stresses that it would be advisable for the King to establish the post of Protocirujano of the Principality, in spite of legal and political objections to the suggestion. [Josep Vilar], A la pretensión de Proto-cirujano, Barcelona, 1657, p. 14.

${ }^{74}$ AHCB, Gremis, XI-2. 


\section{Àlvar Martínez-Vidal and José Pardo-Tomás}

for this. ${ }^{75}$ But because of the situation the funds were not immediately forthcoming. Nevertheless, dissections continued to be performed in the annexe to the corralet $^{76}$

In 1659 the Consell was finally able to pay the 80 pounds needed to restart the refurbishment. ${ }^{77}$ Undoubtedly, as Antoni Cardoner has pointed out, the recently signed peace between France and Spain provided hope of a period of stability for the city finances after almost two turbulent decades of war and epidemics. The same year was marked by another important event, since it was then that Joan d'Alòs (1617-1697) sat the examinations for master of anatomy, which were essential for candidates for a professorship at the Estudi. Cardoner does not hesitate to attribute to "the brilliant anatomical demonstrations Alòs made from the chair and the crowds that attended them" the agreement in 1660 by which the Consell payed a further 60 pounds so that work on the anatomy theatre could continue. The engraved stone with the inscription "Theatrum Anathomicum" that can still be seen in a doorway of the hospital dates from that very year. ${ }^{78}$ Without wishing to make such a direct connection between the two events, it is true that Alòs' scientific work during those years when the theatre was being finished was focused on the teaching and the practice of anatomy.

Joan d'Alòs' well known work, De corde hominis disquisitio physiologica-anatomica (1694), is a product of the environment of intense interest in anatomy found in Barcelona at this time. With the exceptions of Saragossa and Valencia, this was not usual in the Iberian peninsula of the seventeenth century. In his book, Alòs defended the doctrine of the circulation of the blood and showed his first-hand knowledge of the most modern European authors. In addition, he referred to some dissections he had carried out in the Barcelona theatre. ${ }^{79}$ His outstanding academic career, as well as his no less notable political and professional ones, made him a key personage in the Catalonian medical world of this last third of the seventeenth century. ${ }^{80}$

It is worth remembering that Francesc Feu, who in 1689 was appointed the first professor of anatomy at the General Hospital of Madrid, received his anatomical training in the Barcelona theatre. ${ }^{81}$ Feu studied medicine at the Estudi General and received his doctorate

${ }^{75}$ AHCB, Deliberacions, Consell de Cent, II-153, fol. 374; Cardoner, op. cit., note 70 above, p. 389, seems to have seen the document although he does not quote it. However, A M Perelló reproduces a passage in her article, 'L'Aula d'Anatomies i la Casa de les Comèdies: dos establiments vinculats a l'Hospital de la Santa Creu (segle XVII)', Barcelona. Quaderns d' Història, 1995, 1: $85-94$, on p. 89.

${ }^{76}$ There is much evidence to support the idea that the practice of dissection continued in the pati (patio, courtyard) of the hospital cemetery in the middle of the seventeenth century. For instance, documents relating to the autopsies performed during the plague of 1651 ; testimonies that the professor had effectively performed the twelve anatomies a year that the regulations stipulated; and the fact that the doctors of medicine had to take an exam that qualified them in la art de anatomia as a prerequisite for entering the public examination for the professorship of anatomy. See Martínez-Vidal, Pardo-Tomás, op. cit., note 68 above, p. 18 .
${ }^{77}$ AHCB, Deliberacions, Consell de Cent, II-168, fol. 69v. Quoted in Perelló, op. cit., note 75 above, p. 90 .

${ }^{78}$ Cardoner, op. cit., note 70 above, p. 390.

F A Vilarrubias, Noticia histórica-arquitectónica de los edificios del antiguo Hospital de la Santa

Cruz y Casa de Convalescencia de San Pablo de la Ciudad de Barcelona, 1401-1928, Barcelona,

Diputación Provincial de Barcelona, Biblioteca Central, 1969, p. 49.

${ }^{79} \mathrm{~J}$ d'Alòs, De corde hominis, disquisitio physiologico-anatomica, Barcelona, Antonio Ferrer and Baltasar Ferrer for J Gascon, 1694, pp. 214-15, 218.

${ }^{80}$ In spite of his importance, a comprehensive study of Joan d'Alòs remains to be written. For a list of work concerning him, see Martínez-Vidal, Pardo-Tomás, op. cit., note 68 above, p. 23.

${ }^{81}$ For the professorship and the anatomical theatre of Madrid, see Pardo-Tomás, Martínez-Vidal, op. cit., note 37 above, pp. 10-15. 


\section{Anatomical Theatres in Early Modern Spain}

in 1672. Five years later, in 1677, he went to the recently refurbished anatomical theatre, to be examined in public for the qualification of "master of anatomy". 82

The improvements being made to the anatomical theatre of the Hospital de Santa Creu were completed around this time. The contract between Sebastià Català and the city council, "as master builder and carpenter, concerning the anatomical classroom in this City General Hospital" was signed on 3 October $1673 .{ }^{83}$ Català undertook to carry out the work, both bricklaying and carpentry, complying with the city council's specifications and its budget of 150 pounds. Thanks to these detailed requirements, we know the architectural features of the theatre, the disposition of the stands for the audience and some details of the dissection table that was installed.

As previously noted, it is clear that the building work restored a pre-existent structure that consisted, apparently, of a square open air area, measuring thirty-two pams (something more than six metres ${ }^{84}$ ) each side. Access was through a doorway in one of the four walls. The plans for the renovation works respected this structure, but they proposed making the building higher and covering it with a roof. For this, eight square-section pillars-one brick and a half in width-were raised upon those already in place. The height of these new pillars had to be the same as that of the existing ones, thus making the walls, which were plastered on the inside, a total height of more than three metres. The roof was to be hipped and made of curved roof tiles. The existing doorway was to be kept, but now it must have a door that could be closed with "lock, key and padlock inside". Wooden tiers of seats at three different levels for the students were to be erected inside, around the entire perimeter. Català was to build these stands using as a model one that had recently been built in a new classroom of the Estudi General.

One of the most interesting descriptions is that of the dissection table placed in the centre of the space between the stands. The table top was made of cut granite, about two metres long by about eighty centimetres wide. It was supported on a single pedestal, also of stone, with a hole in its centre "to insert a rotating iron [pivot] which could make the table turn easily when anatomies were performed as well as when the table was cleaned". ${ }^{85}$ Liquids and other organic matter were evacuated through the central hole of the table and the hollow iron pivot, from which a drain carried the waste matter into a cesspool of almost one and a half metres deep placed outside the building and covered with paving stones.

Under the terms of the contract, Sebastià Català was obliged to finish the bricklaying work on 15 October and the carpentry on 31 October 1673. The master builder Pere Pau Ferrer and the carpenter Miquel Salta acted as the contractor's guarantors before the city consellers.

With these important improvements, the primitive anatomical theatre of Barcelona, established in 1573 as an anatomical classroom near the hospital cemetery, ended its first hundred years. From then on, it functioned continuously, until the Estudi General

\footnotetext{
${ }^{82}$ AGP, Sección Administrativa, Box 12061, file 2 .

83 “... tocants a mestre de cases y fuster en la aula anotòmica del corralet del hospital general de la present Ciutat", AHCB, Manuals, Consell de Cent, XIII-64, unpaginated.
}

\footnotetext{
${ }^{84}$ According to J Corominas' Diccionari etimològic (Barcelona, 1980), the pam of Barcelona is equivalent to $19.44 \mathrm{~cm}$

85 ، ... f ferro amb invensió que puga rodar dita taula ab facilitat que convinga quan se fan les anatomies y quan se renta la dita taula", $\mathrm{AHCB}$, Manuals, Consell de Cent, XIII-64, unpaginated.
} 


\section{Àlvar Martínez-Vidal and José Pardo-Tomás}

was forced to close it following the invasion of Barcelona by the troops of Philip V in 1714. When, in 1760, the decision was taken to build the new Royal College of Surgeryconceived by Pedro Virgili using as model one that had just been erected in Cadiz-the site chosen was once again next to the cemetery on land expropriated from the hospital. ${ }^{86}$

\section{Saragossa}

The first evidence regarding the practice of anatomical dissection in Saragossa dates back to the privilege granted in perpetuity in 1488 by Ferdinand the Catholic to the College or Brotherhood of St Cosmas and St Damian. According to this, it was left to the discretion of the city physicians and surgeons to perform as many dissections as they considered appropriate on the bodies from the Hospital General de Nuestra Señora de Gracia: "Firstly, whenever either the physicians and surgeons of the said brotherhood [of St Cosmas and St Damian], or the physicians and surgeons of the Spital de Sancta María de Gracia intend to practise anatomy on any corpse in the said Hospital, they can perform the anatomy on that body, either on the whole of it or on some of its parts, whether it be a man or a woman, as many times a year as they consider appropriate, without them incurring any penalty". 87

So that this provision could be fully complied with in practice, the royal document added that "during the said anatomy, no person of any status or condition will dare to cause any impediment, on pain of [paying] a thousand sueldos", a very large fine. The only obligation imposed was that "the Physicians and Surgeons of the said Brotherhood must be summoned in such cases so that every one of them who wishes to be present, can go, and contribute if any expenses arise from it". ${ }^{88}$ That is to say, by granting this privilege, the king, more than simply granting permission for a previously non-existent practice, was prepared to punish and penalize anyone who dared to obstruct it. Thus he acknowledged the right of the physicians and surgeons to perform dissections in the hospital without any restrictions. In so doing, he sanctioned an already existing practice.

It was thus that at the end of the fifteenth century, an anatomical tradition, based on the practice of dissection and linked both to a guild and to a hospital, emerged in Saragossa, a city which lacked a university. It is not at all strange, therefore, that some time later,

\footnotetext{
${ }^{86}$ J Danón, Visió històrica de l' Hospital General de Santa Creu de Barcelona. Barcelona, Fundació S. Vives Casajuana, 1978, p. 33. It seems clear that the place that Virgili chose for the setting of the College was precisely "the plot where the classroom of anatomy was situated" ("la parcela donde asentó el Aula de les Anatomies"): D Ferrer, Biografía de Pedro Virgili, Barcelona, Tipografía Emporium, 1963, pp. 327-8.

87 “Primo, que toda vegada que por los Meges y Cirujanos de la dicha cofraría [de San Cosme y San Damián], o por los Meges y Cirujanos que visitarán en el Spital de Sancta María de Gracia será deliberado obrir o anatomizar algún cuerpo muerto en el dicho Spital, lo puedan obrir o anatomizar todo o en parte, agora sea de hombre agora de mujer, tantas cuantas
}

vezes en cada un anyo a ellos será visto, sinse incorrer en pena alguna." A Fernández Doctor, Documentos para la historia de las profesiones sanitarias: el Colegio de Médicos y Cirujanos de Zaragoza (siglos $X V-X V I I I)$, Zaragoza, Colegio Oficial de Médicos de Zaragoza, 1997, pp. 40-4, on p. 41. The royal privilege included not only the members of the College, but also all those physicians and surgeons who practised in the Nuestra Señora de Gracia General Hospital.

88 ، ... en la tal anatomizazión ninguna persona de qualquier estado o condición sea, no presuma ni ose poner empacho alguno sus pena de mil sueldos"; "en la tal obra ayan de ser clamados los Meges, y Cirujanos de la dicha Cofraría para que hi sean, los que hi querrán ser, y contribuir si algunos gastos acerca de aquello se avrán de facer". Ibid., p. 41. 


\section{Anatomical Theatres in Early Modern Spain}

the Royal and General Hospital of Nuestra Señora de Gracia, home to the brotherhood of St Cosmas and St Damian, was the place where the Sardinian physician Juan Tomás Porcell performed systematic autopsies on the bodies of those who died in the 1564 plague epidemic. Having taken charge of the hospital during the plague, Porcell performed these autopsies with the specific purpose of contributing to the knowledge of the disease and of finding an effective treatment, as López Piñero has shown. ${ }^{89}$

Nevertheless, the construction of a room specifically for the practice of dissection in this hospital did not take place until almost the end of the sixteenth century, when it coincided with the movement to found a university led by Archbishop Pedro Cerbuna. On 27 March 1586, the town council of Saragossa asked Andrés de Capraneda, a builder, to construct a house of anatomy in the hospital cemetery within a period of two months. ${ }^{90}$

According to the notarial agreement entitled 'Capitulación para hazer la Casa de Anathomia', ${ }^{91}$ this house was a square building located in the hospital cemetery, each side measuring thirty palmos in length $(5.79 \mathrm{~m}) .^{92}$ The pillars were made of brick and the "Valencian walls" (a type of adobe) were twenty-four palmos $\left(4.63 \mathrm{~m}\right.$.) high. ${ }^{93}$ There were two windows on each side of the building four palmos high $(0.77 \mathrm{~m})$ and at least five palmos wide $\left(>0.96 \mathrm{~m}\right.$.) ${ }^{94}$ The wooden dissection table was about nine palmos long

${ }^{89}$ Juan Tomás Porcell (1528-c.1580), born in Cagliari, Sardinia, was a pupil of Lorenzo de Alderete and Cosme de Medina at the University of Salamanca. Both men played an important part in the dissemination in Castile of the Vesalian reform of anatomy. J M López Piñero, M L Terrada Ferrandis, 'La obra de Juan Tomás Porcello (1565) y los orígenes de la anatomía patológica moderna', Medicina Española, 1965, 52: 237-50. J T Porcell Sardo, Información y curación de la peste de Caragoça y praeservación contra la peste en general, Zaragoza, Viuda de Bartolomé de Nágera, 1565 , ch. 3 , fols. $3 \mathrm{v}-8 \mathrm{v}$. Francisco Huguet, professor of anatomy at the University, and Joseph Estiche, chief surgeon at the hospital, also performed several autopsies on people who had died in the plague epidemic that devastated Saragossa in 1652, in order to discover the nature of the disease and to back up the preventive and therapeutical measures used. See J Estiche, Tratado de la peste en Caragoça, en el año 1652, Pamplona, por Diego de Zabala, 1655, pp. 16-19. For the effects of this epidemic, see also J Maiso González, La peste de 1652 en Zaragoza, Zaragoza, Institución Fernando el Católico, 1980.

${ }^{90}$ A San Vicente, Monumentos diplomáticos sobre los edificios fundacionales de la Universidad de Zaragoza y sus constructores, Zaragoza, Institución Fernando el Católico, 1981, pp. 7-9, 167-8.

${ }^{91}$ Archivo Histórico Provincial de Zaragoza (hereafter AHPZ), Protocolos Notariales, Martín Español, año 1586, fols. 143-146.

${ }^{92}$ The palmo of Saragossa is approximately equivalent to $19.3 \mathrm{~cm}$. See Pesas, medidas y monedas ( segunda edición). Resumen de las unidades usadas en distintas provincias de España, [Madrid], Dirección General de Agricultura, Servicio de Publicaciones Agrícolas, c. 1930, p. 147.

\footnotetext{
${ }^{93}$ A Baquero, Bosquejo histórico del Hospital Real
} y General de Nuestra Señora de Gracia de Zaragoza, Zaragoza, Institución Fernando el Católico, 1952, p. 54: "the Cemetery was walled in and divided into two parts: one of them for the purpose of burials, and the other, since it had the stations of the Via Crucis and the statue of the Mother of God, was used as a place of worship, inside which was the morgue and the room where the doctors and professors of the University performed the anatomies"; ("El Cementerio, que estaba tapiado y dividido en dos partes: la una destinada a enterramientos, y la otra, que por tener las estaciones del Vía Crucis y la estatua de la Madre de Dios, servía de calvario, encontrándose en su interior el depósito de cadáveres y el aposento donde los médicos y

catedráticos de la Universidad hacían las anatomías"). Unfortunately, Baquero does not give the source of this information.

${ }^{94}$ According to a report written after a tour of inspection carried out at the hospital at the beginning of the seventeenth century, which says that the anatomical theatre was situated next to the cemetery, the building had apparently only four windows: "Across [the road] there is a room with its lock and key and four windows with its wooden shutters that the surgeons and professors and physicians of the University use for performing anatomies"; ("A otro lado [del camino] es el aposento que sirve de hazer lanatomia los cirujanos y Cathedraticos de la Universidad y medicos della con su cerraja y llave y quatro ventanas con sus balagostes de madera"). Archivo de la Vicaría del Hospital Provincial de Nuestra Señora de Gracia de Zaragoza, 'Libro de Visitas del Hospital año de 1600 en adelante [1600-8]', p. 661. We are grateful to Asunción Fernández Doctor for this information. 


\section{Àlvar Martínez-Vidal and José Pardo-Tomás}

$(1.73 \mathrm{~m} .-1.93 \mathrm{~m}$.) by four wide $(0.77 \mathrm{~m}$.$) , and it was placed in the middle of the room$ almost one metre below the level of the ground. Some steps led down to it from the entrance. The smooth surface of the table was edged with a raised border. The body fluids drained through a hole located on one side, which connected with a drain. The eight ringszercillos according to the 'Capitulación' - placed on both sides of the table, indicated that whoever designed it considered the possibility of animal vivisections being carried out too. The table was supported on a single one-metre-high base. At floor level surrounding the table top and somewhat lower, a brick parapet described a circle nearly two metres in diameter so that the table could rotate on its base without encountering any obstacles.

At a distance of one grande tercia de vara (approximately $0.30 \mathrm{~m}$ ) and at about the same height or slightly lower was the first level of the stands also circular in shape. The second stand was almost three palmos $(0.58 \mathrm{~m}$.) higher than the first and situated one gran tercia de vara from the one below. The same applied to the third level. That is to say, in spite of the square ground plan, it was in fact a round theatre with a central table. The three stands were placed in such a way that the audience could sit on two "long benches" forming a circle. Since the table's support was lower than the floor, the table's surface was on a level with the feet of the members of the audience sitting in the front row. This arrangement guaranteed a close and good view of the corpse during the dissection. In addition, in one of the corners, the theatre had a cupboard with a shelf, in which the instruments for dissection could be kept under lock and key. The floor was paved in brick, and the walls, window embrasures and roof finished with plaster. The tiled roof ended in wide eaves, in the Aragonese style.

The construction of this "house of anatomy" met the requirements contained in Pedro Cerbuna's statutes of 1583, for the inclusion of the anatomy "of a corpse or some parts of it" in the medical students' curriculum. These first statutes had even foreseen the problems of the supply of corpses, and directed that a licence from the viceroy should always be available for the use of the bodies of executed criminals for anatomical purposes. Likewise, the aldermen were required to allow the autopsies of the bodies of those who died in the hospital, usually foreigners. A licence was necessary because the dissection was a public event which sought to bring together a diverse audience of students of medicine, mancebos (apprentice surgeons) and the general public, as well as members of the College of Physicians and Surgeons. In any case, it must also be understood as a way of involving the authorities, especially the viceroy of Aragon, in the legitimacy of the new university. The university regulations also considered the possibility that an appropriate corpse would not be available when needed, which could often happen due to the frequency of classes in the academic schedule. In such cases, they had to resort to showing "the images and pictures that there are of it". 95

\footnotetext{
95 ،... de algún cuerpo humano o parte del, procurándose por parte de la universidad de haber cuerpos humanos de algunos ajusticiados con licencia del virrey o del hospital de los regidores y faltándolo muestren en las figuras y estampas que dello hay". Archivo de la Corona de Aragón, Secretaría de Aragón, leg. 79, Fundación y creación de la Universidad y
}

Estudio General de la ciudad de Zaragoza y los Estatutos y Ordinaciones della, en el año MDLXXXIII, Statute 31, "De los catedráticos de Medicina", 1. 1170. Quoted by M Jiménez Catalán, J Sinués y Urbiola, Historia de la Real y Pontificia Universidad de Zaragoza, 2 vols, Zaragoza, Tipografía "La Académica", 1923, vol. 2, p. 10. 


\section{Anatomical Theatres in Early Modern Spain}

Undoubtedly, both the compulsory anatomical dissections laid down by the statutes of 1583 , and the construction of the anatomical theatre itself with the economic support of the town council in 1586, were parts of a preconceived plan to consolidate the new University of Saragossa in the face of its neighbouring rival in the kingdom of Aragon, the older University of Huesca, founded in $1354 .{ }^{96}$

During the next hundred years, many dissections must have taken place in the Saragossa anatomical theatre. According to the University statutes of 1659, the professor of anatomy had to perform eighteen dissections a year-six of the complete body, twelve of parts of the body-in an established order, between St Luke's day, 18 October, and 1 March. The statutory regulations were extremely harsh and coercive, since, for instance, a heavy fine of 20 reales was stipulated for every dissection that was not carried out. The person who reported the offence would receive a third of the fine and the remainder was destined for the University coffers. ${ }^{97}$

Apart from the teachers and students of the Faculty of Medicine, both the College of Physicians and Surgeons and the Hospital General de Nuestra Señora de Gracia urged others to attend the dissections. Thus, in 1649, the College ruled that anyone who wanted a licence to work as a midwife in Saragossa was required, among other things, to attend the autopsies that the professor of anatomy had to carry out especially for them: "We require and order the Professor of Anatomy to perform privately for the midwives the anatomies considered necessary on the appropriate parts, with suitable tact and discretion, and the

\footnotetext{
${ }^{96}$ The University of Huesca regarded with some suspicion the establishment of a new university so close to it and feared for its own survival. Therefore, it opposed Pedro Cerbuna's initiative and brought a prolonged lawsuit against the University of Saragossa. F Solano Costa, 'Pedro Cerbuna y el funcionamiento de la nueva Universidad', in Historia de la Universidad de Zaragoza, Madrid, Editora Nacional, 1983,pp. 101-7.

97 "[The professor of Anatomy] will perform 18 dissections from Saint Luke's day to March $1^{\text {st }}$; six of them must be of the complete body and twelve of parts of the body; and whenever he does not perform it, the fine will be of [twenty] reales. Two thirds of the money will be for the Coffers and the remaining third part for the accuser. The anatomies must be performed on the three cavities, on the head, on the eyes, on the nose, on the ears, on the tongue, on the larynx, on the arms, on legs, on the uterus; and finally on whatever other small parts there may be in the human body. The general autopsies must be done on the veins, taking them from their origin, that is the liver, and following them through all the parts of the body in which they branch. The following year, the Anatomy will be performed on the arteries, starting from the heart, and following them everywhere they go. The third year the autopsies must be performed on all the nerves, starting from the brain", ("Hará [el catedrático de anatomía] 18 disecciones desde el señor san Lucas, hasta primero de Março, es a saber: seis universales, y doce particulares; y tenga pena
}

por cada vez que lo dejara de hacer, [veinte] reales; las dos partes para el Arca, y la tercera parte [para] el denunciador; y sean las tres cabidades [sic], de la cabeça, de los ojos, de las narices, de las orejas, de la lengua, de la laringe, de los brazos, de piernas, del útero; y finalmente de cualesquiera particulas en el cuerpo humano se hallan; y las generales sean de las venas, tomándolas de su origen, que es el hígado, y siguiéndolas por todas partes del cuerpo; en que se ramifican. Otro año de las arterias, començando desde el coraçón, y prosiguiendo todas por las partes, en que van a parar. Otro año de todos los nervios, començando desde el celebro"). Estatutos de la Universidad y Estudio General de la ciudad de Caragoça confirmados por la Majestad Católica de Felipe IV, Title 34, pp. 60-1. According to the statutes of 1597 and those of 1618 , the professorship of anatomy was provided with 60 pounds and 60 escudos respectively. By comparison with some other university professorships and even with the rest of the Medical Faculty, it was the worst paid, except for that of surgery. Jiménez Catalán, Sinués y Urbiola, op. cit., note 95 above, vol. 2, pp. 12-17. The statutes of 1625 assigned 90 pounds to the professor of "Anatomy and Medical Botany" and those of 1645, 50 escudos, whereas those of 1684,50 pounds. It has not been possible to discover whether the professor earned a bonus, in money or in kind, for each anatomy accomplished. 


\section{Àlvar Martínez-Vidal and José Pardo-Tomás}

women will be obliged to go to the Hospital Camarilla [small room] or wherever they are told to go, on the date and time fixed by the Professor". 98

Similarly, the Hospital's internal Ordinaciones, the specific regulations running this great welfare centre, clearly reveal the importance of anatomical dissection for anyone wanting to practise surgery in Saragossa. The Ordinaciones of 1681 are most interesting because they not only affirm the value of the practice of anatomy for surgeons, but also reveal the existence in the hospital of an "anatomical dissector", responsible for the theatre's instruments and equipment, whose duty was also to summon the professor to all the anatomies performed.

Believing that the practice of anatomy is most necessary for the perfection of a surgeon, and that special and large benefits to the public weal result from frequent and properly carried out anatomical dissections, the anatomical dissector that is and will be in the said Hospital, is ordered to summon the Professor of Anatomy at the time set for the revisions, every Saturday and whenever any corpses are available. He will do this in the accustomed manner, making sure that the Theatre is meticulously clean, having in his custody the keys and whatever is required for the anatomical demonstration, and he also will take care of the anatomical irons and their case, which the Hospital keeps for this purpose and for which the aforementioned dissector is responsible. ${ }^{99}$

Linked, on the one hand, to the University and, on the other, to the General Hospital, this theatre was, around 1675, the setting in which the Italian Juan Bautista Juanini, ${ }^{100}$ the personal surgeon of Prince Juan José de Austria, mainly performed his anatomical demonstrations confirming the doctrine of the circulation of the blood, showing the role of the venous valves in the centripetal motion of the blood. ${ }^{101}$ It is not, therefore, surprising that the anatomical theatre of Saragossa became well-known. Evidence of this is the mention by the Sicilian physician Federico Bottoni, in his Evidencia de la circulación de la sangre (Lima, 1723) of the importance of Saragossa's Hospital de Nuestra Señora de Gracia and

98 “Ittem, estatuimos y ordenamos que el Catredático [sic] de Anatomía que es, o, por tiempo será, sea tenido y obligado hacer las anathomías que parecieran necesarias de las partes convenientes al dicho exercicio de parteras a ellas privadamente, con el recato y compostura conveniente, y las dichas tengan obligación de acudir a la Camarilla del Hospital, o puesto que se les señalara, el día y hora señalado por dicho Catedrático." AHPZ, Protocolos Notariales, Juan Francisco Sánchez del Castellar, 1649, fol. 976, Colegio de Médicos y Cirujanos de Zaragoza. 'Ordinaciones para parteras'. Quoted in Fernández Doctor, op. cit., note 87 above, pp. 122-5, on p. 124.

99 "Considerando que el ejercicio anatómico es el más preciso para la perfección de un cirujano, y que de la repetición y buen método en las disecciones anatómicas resultan especiales y grandes beneficios al bien público, se ordena al disector anatómico, que es y será en dicho Hospital, que en el tiempo arriba prefijado para los repasos, todos los sábados y siempre que haya ocasión oportuna de cadáver, tenga obligación de avisar al Catedrático de Anatomía en la forma que se ha acostumbrado para el acto de la disección cuidando de que el Teatro se halle con la limpieza y prolijidad correspondiente, teniendo a su custodia las llaves y lo que se requiere para hacer demostrables las partes, y cuidando del estuche y hierros anatómicos que a este fin tiene el Hospital de que es responsable dicho disector." Quoted in A Fernández Doctor, El Hospital Real y General de Nuestra Señora de Gracia de Zaragoza en el siglo XVIII, Zaragoza, Institución Fernando el Católico, 1987, p. 330. These Ordinaciones of 1681 were added to those of 1655 in the section entitled "Para la instrucción y adelantamiento de los sirvientes cirujanos"; ("For the apprentice surgeons' learning and improvement").

${ }^{100}$ For Juanini's place in the novator movement, see J M López Piñero, 'Giovanibattista Giovannini (1636-1691) e gli inizi in Spagna della medicina moderna e della iatrochimica', Castalia, 1965, 21: 89-98.

${ }^{101}$ J B Juanini, Discurso político y phísico, Madrid, 1679, fol. 46r-46v: "[the valves of the veins] are palpable, as my Teacher of Anatomy taught me at the University of Pavia, where I learned, and practised this discipline from 1660 to 1663 and afterwards I lectured on it at the Universities of Salamanca and Saragossa ... and therefore, those who still insist on being against it [the circulation of the blood], should 


\section{Anatomical Theatres in Early Modern Spain}

his extremely complimentary reference to the dissections that took place regularly in the anatomical theatre at the end of the seventeenth century. As he reminds us, it was there that the doctrine of the circulation of the blood was taught regularly from 1686 by the professor of anatomy. ${ }^{102}$

At the famous University of Saragossa, in the Court of the Kingdom of Aragon, Doctor Don Francisco San Juan y Campos, prebendary of that metropolitan holy church and, at that time, Professor of Anatomy and, later, of Prima de Medicina, supported and established this doctrine, with notable acclaim worthy of his subtle and ingenious talent; the whole of the school accepted this doctrine, which was established as an elementary principle; due to this achievement, in my view, the fame of the University of Saragossa was increased, since nobody in Europe is unaware that in this celebrated museum of the sciences, Medicine flourishes at its highest level, due to the continual practice of anatomy that twice a week is performed in the theatre or room provided for this purpose in that famous General Hospital; all the professors of this science having attended such an important demonstration [of the circulation of the blood]. ${ }^{103}$

\section{Conclusion}

To conclude this brief overview of what is known so far about the circumstances under which anatomy was practised in early modern Spain, it is perhaps worth reiterating that two different models existed-one in Castile, the other in Aragon-in which three elements feature: the differing roles of the Crown and of the municipalities; the ways in which the university teaching of anatomy was consolidated and continued; and the placing of anatomical theatres in hospital precincts.

carry out the experiments which others have done so as to undeceive themselves and know the truth (which is very necessary for Physicians and Surgeons)"; (“... [las válvulas de las venas] son palpables, como demostrativamente me las enseñò mi Maestro de Anotomía de la Universidad de Pavía, en donde aprendí, y practiquè esta facultad desde el año de 60 hasta el de 63 y después las he mostrado en las Universidades de Salamanca y Zaragoça ... y assí los que todavía estàn obstinados contra ella [la circulación de la sangre], hagan las experiencias, con las quales otros se han desengañado, y veràn la verdad (qual es muy necessaria para los Médicos, y Cirujanos)", fols. $46 \mathrm{r}-46 \mathrm{v}$ ). In the same work (fol. 24r), Juanini mentions that, in the same theatre, he had found a polyp of fleshy appearance in the course of a dissection of the cranial cavity: "In 1655 I have seen a similar one in the Hospital of Milan, in a person that died suddenly, and at the anatomical Theatre of Saragossa when I was dissecting the head of a corpse, in the presence of Doctor Serrano, Professor of Anatomy, and of Doctor Sanz Mostrelt, in the Sinu de la Falsmisoria, and in the jugular veins, the blood being solid and fibrous and having the appearence of flesh"; ("De la misma suerte lo he visto yo en el Hospital de Milán, el año de 1655, en uno que murió de repente, y en Zaragoza, disecando la cabeça de un cadáver, en el Theatro anatómico de dicha Ciudad, a la presencia del Doctor Serrano, Cathedrático de Anatomía, y del Doctor Sanz Mostrelt, en el Sinu de la Falsmisoria, y en las venas jugulares, la sangre concreta, y fibrosa del modo, y forma de la carne.")

${ }^{102}$ Francisco San Juan y Campos was a priest and the incumbent of Saint Philip [Neri]'s Church of Saragossa. He was appointed to the professorship of anatomy in 1686, he held that of Vísperas in 1701, and two years later, that of Prima. He died in 1705. Hernández Morejón, op. cit., note 10 above, vol. 7, pp. 7-8

103 "En la célebre Universidad de Zaragoza, Corte del Reyno de Aragòn, propugnó y estableció esta doctrina el Doct. D. Francisco San Juan, y Campos, Racionero de aquella Santa Iglesia Metropolitana, y Cathedrático entonces de anathomía, y después de Prima de Medicina, con singular aplauso, digno de su delicado, y perspicaz ingenio, siguiendo todo el resto de la escuela, esta doctrina, que quedó establecida, como principio elemental, subiendo a mi intento, de mucha authoridad esta aceptación, pues nadie de los Europeos ignora, que en este celebrado Museo de las Sciencias, floreçe la Medicina, en el más elebado crédito, debiéndose éste al continuo exercicio anothómico que dos vezes a la Semana se executa en el Theatro, o Salón, que para este efecto hay en aquel célebre Hospital General, concurriendo todos los Professores de esta sciencia a tan importante demostración [la circulación de la sangre]". F Bottoni, Evidencia de la circulación de la sangre, Lima, Imprenta de la Calle de Palacio, 1723, H4v-Ir. 


\section{Àlvar Martínez-Vidal and José Pardo-Tomás}

In the cities of Castile discussed above, the Crown played an important part in the practical teaching of anatomy and, as a result, in the continuing practice of dissection in their universities. Royal intervention is evident both at the initial stages, in the midsixteenth century, and even a century later, with the establishment in Madrid of a professorship and the anatomy theatre. In addition, these events coincide with two more general developments in which Spain participated politically and culturally: the Vesalian reforms (a reductionist term that should perhaps be reconsidered) and the novator movement in Spain at the end of seventeenth century.

Secondly, the consolidation of anatomical studies in institutions and of the regular practice of dissection with an educational purpose created some problems in Castile, especially in Alcalá and Valladolid, which require further research in order to be explained satisfactorily. A wide variety of factors seem to have been involved in the whole process: from the views of prestigious medical figures at the time, to pressure from students, and the professional expectations of some physicians and surgeons tempted by higher positions or a career at Court— to which mainly Castilians were appointed.

Thirdly, with regard to the specific building in which these dissections with an educational purpose were performed, the case of Salamanca stands out, partly because of its early date, but also because it does not follow the town council and hospital model, which was common in the Crown of Aragon. To understand whether this was a peculiarity of Salamanca or of Castilian universities in general, requires more study of the places where anatomy was performed in Valladolid and, particularly, in Alcalá.

Finally, the Madrid anatomical theatre is extremely interesting because it is the sole example in which the three elements mentioned are clearly evident: the active intervention of political power at the highest level, the pressures for and against its construction, and the choice of a model from the periphery (the Crown of Aragon) for the theatre. Although it could be considered a late example if compared with some Italian, Spanish or French universities, yet, when considered in relation to other European institutions, particularly the extra-university anatomical theatres typical of the time, it is not especially so.

As regards the Crown of Aragon, throughout the sixteenth century the practice of anatomical dissection was consolidated in the big hospitals that the municipal governments of its largest cities-Barcelona, Saragossa and, a little later, Valencia-had founded so that the Christian virtue of charity could be exercised collectively, and poverty and begging controlled. The so-called "houses of anatomy" - that is to say, the first permanent anatomical theatres, associated with university teaching - appeared in the "general hospitals".

In fact, during the fifteenth and sixteenth centuries, cities such as Barcelona, Valencia and Saragossa developed a firm municipal policy aimed at centralizing and rationalizing the care of the destitute and the poor, by legally unifying and physically concentrating under the generic denomination of "general hospital" the small charitable institutions, scattered through these urban areas, which had been created and were economically supported by the contributions and bequests of well-off members of the Church, aristocracy and merchant class. Barcelona adopted this model of welfare when the Hospital General de Santa $\mathrm{Creu}^{104}$ was founded in a poor area on the outskirts of the city in 1401; and Saragossa

\footnotetext{
${ }^{104}$ Danón, op. cit., note 86 above. In 1401 the Studi de Medicina received a royal privilege for practising
}

dissections from King Martin I, about ten years earlier than the University of Lleida. The royal privilege 


\section{Anatomical Theatres in Early Modern Spain}

did likewise in 1428 when it built the Nuestra Señora de Gracia General Hospital ${ }^{105}$ outside the city walls next to the convent of San Francisco. Somewhat later, in 1512, Valencia succeeded in concentrating its charitable activities in a single location, the General Hospital, built near the city walls, in the vicinity of the convent of Sant Agustí and the church of Santa Llúcia. ${ }^{106}$

Undoubtedly, the location of anatomical theatres in such hospitals facilitated the supply of corpses for dissection, since many of the inmates were marginalized individuals (often "outsiders" or foreigners), who, in the main, lacked the means to pay the expenses of a funeral and had no relatives in the city who would claim their bodies for burial.

As these cities became politically, economically and ecclesiastically consolidated as capital cities of their respective territories, they created and promoted their own universities, which included the study of medicine. Therefore, the universities of Lleida (1300), Perpignan (1350) and Huesca (1354), which had had moments of splendour in previous centuries, entered a period of irreversible decadence during the Renaissance. ${ }^{107}$ Thus, Lleida lost its primacy in Catalonia due to the strength of the University of Barcelona, ${ }^{108}$ founded in 1559, while the hegemony of Huesca within the Kingdom of Aragon was questioned when the University of Saragossa was opened in $1583 .{ }^{109}$ However, Valencia, which did not have to compete with any other cities in its surrounding area, preceded the other two in creating its own university in $1499 .{ }^{110}$ On the other hand, the determination of these universities to teach medicine compelled them to establish agreements with the guilds that monopolized the exercise of medicine and surgery and granted licences for the practice of medicine in their respective demarcations, after compulsory examination and the payment of the corresponding fees.

The regular practice of anatomical dissections, as performed within the physicians and surgeons' corporations, resulted eventually in the need for suitable premises. However, the fitting out of a permanent building took place when the above mentioned universities demanded in their statutes the regular practice of dissection. Thus the professor of anatomy was required to perform a certain number of dissections annually and the medical students

followed the model established in Montpellier in 1340 that ordered the dissection of one corpse every two years. A Cardoner i Planas, Història de la medicina a la Corona d'Aragó(1162-1479), Barcelona, Ed. Scientia, 1973,pp. 134-6. A transcription of the document can be found in A Torre y del Cerro, Documentos para la historia de la Universidad de Barcelona, Barcelona, Facultad de Filosofía y Letras, 1971, pp. 103-5.

${ }^{105}$ Fernández Doctor, op. cit., note 87 above, pp. 38-9. Baquero's work, op. cit., note 93 above, remains useful.

${ }^{106}$ After the failed attempt of 1482 , which for economic and political reasons did not prosper, the three Valencian hospitals were finally amalgamated in 1512 when the town Consell appointed a commission designed for that purpose. It was made up of representatives from the Consell, the cathedral chapter, and the powerful Hospital dels Ignocents. See M Gallent Marco, 'El proceso de unificación de los hospitales valencianos (1400-1512), in Estudios dedicados a Juan Peset Aleixandre, op. cit., note 56 above, vol. 2, pp. 69-84; López Terrada, op. cit., note 64 above, pp. 331-7.

${ }^{107}$ Cardoner i Planas, op. cit., note 104 above, pp. 78-85; M McVaugh, L García Ballester, 'The medical faculty at early fourteenth-century Lérida', History of Universities, 1989, 8: 1-25.

${ }^{108}$ The Studi de Medicina-which claimed a monopoly on teaching-regarded the establishment of the University with some suspicion. The agreement between those institutions, signed in 1565 , put an end to their disputes and as a result medical studies in Barcelona flourished. Fernández Luzón, op. cit., note 69 above.

${ }^{109}$ Jiménez Catalán, Sinués y Urbiola, op. cit., note 95 above, vol. 2, pp. 8-12.

${ }^{110}$ For the establishment of the University of Valencia, see A Felipo Orts, La Universidad de Valencia durante el siglo XVI (1499-1611), Universitat de València, 1993, pp. 17-20. 


\section{Àlvar Martínez-Vidal and José Pardo-Tomás}

were obliged to attend them. The dissections had to be supervised by a university professor and the manual work done by a dissector who had to be a surgeon from the hospital. The dissector was also responsible for the anatomical instruments and for the installations. At first, the regulations anticipated only a few anatomies per course; however, as time went by, the number rose to the eighteen a year required by the University of Saragossa and the twenty-five organized by the University of Valencia at the end of the period. ${ }^{111}$

To sum up, the so-called "houses of anatomy" 112 of Barcelona, Valencia and Saragossa sprang up within the triple institutional framework of the hospital, the guild and the university. This explains the resemblances between them, although each has its peculiarities, and indicates a model of the anatomical theatre shared by these three cities, the most important in the Crown of Aragon at this time. These similarities become even more evident when not only the institutional framework is considered, but also the audience, the building materials and the architectural ground plan.

\footnotetext{
${ }^{111}$ It should be remembered that the number of anatomies was not the same as the number of bodies required, since the regulations distinguished between dissections of the entire body and those of parts of the body.

${ }^{112}$ The term casa de anatomía is probably the most usual, at least in the sixteenth century. It suggests an independent building specifically dedicated to the dissection of corpses. The diminutive caseta (little house) (Valencia, 1586) indicates that the building was small in size and of little architectural value. Aposento (room) (Saragossa, 1586) refers to the
}

room inside the "house" where the dissections were performed. Aula de anatomía (classroom of anatomy) (Barcelona, 1573) reveals the educational, academic nature of the room where the dissections were done and, definitively, the university links with the hospital. Teatro (theatre), much used in the documents relating to the anatomical theatre of Barcelona, was also used in university circles as the classroom where teachers and students met, a meaning that was included in the eighteenth-century Diccionario de Autoridades, Madrid, 1726-39, see vol. 1, p. 485, vol. 6, p. 627. 